\title{
16. SITE 460: INNER WALL OF THE MARIANA TRENCH ${ }^{1}$
}

\author{
Scientific Shipboard Party ${ }^{2}$
}

\section{HOLE 460}

Date occupied: 4 May 1978

Date departed: 6 May 1978

Time on hole: 52.4 hours

Position: $17^{\circ} 40.14^{\prime} \mathrm{N} ; 147^{\circ} 35.92^{\prime} \mathrm{E}$

Water depth (sea level; corrected m, echo-sounding): 6452

Water depth (rig floor; corrected m, echo-sounding): 6462

Bottom felt (m, drill pipe): 6461.5

Penetration (m): 85

Number of holes: 1 of 2

Number of cores: 9

Total length of cored section (m): 85

Total core recovered $(\mathrm{m}): 27.21$

Core recovery $(\%): 32$

Oldest sediment cored:

Depth sub-bottom (m): 76

Nature: calcareous and crystal vitric mud

Age: Eocene

Measured velocity $(\mathrm{km} / \mathrm{s}): 1.57$

\section{HOLE 460A}

Date occupied: 7 May 1978

Date departed: 9 May 1978

Time on hole: 61.0 hours

Position: $17^{\circ} 40.02^{\prime} \mathrm{N} ; 147^{\circ} 35.16^{\prime} \mathrm{E}$

Water depth (sea level; corrected m, echo-sounding): 6445

Water depth (rig floor; corrected m, echo-sounding): 6455

Bottom felt (m, drill pipe): $\mathbf{6 4 5 3 . 5}$

Penetration (m): 99.5

Number of holes: 2 of 2

Number of cores: 11

Total length of cored section $(\mathrm{m}): 99.5$

\footnotetext{
1 Initial Reports of the Deep Sea Drilling Project, Volume 60.

2 Donald M. Hussong (Co-Chief Scientist), Hawaii Institute of Geophysics, Honolulu, Hawaii; Seiya Uyeda (Co-Chief Scientist), Earthquake Research Institute, University of Tokyo, Tokyo, Japan; René Blanchet, Université de Bretagne Occidentale, Brest, France: Ulrich Bleil, Institut für Geophysik, Ruhr Universitat, Bochum, Federal Republic of Germany; C. Howard Ellis, Marathon Oil Company, Denver Research Center, Littleton, Colorado: Timothy J. G. Francis, Institute of Oceanographic Sciences, Surrey, United Kingdom; Patricia Fryer, Hawaii Institute of Geophysics, Honolulu, Hawaii; Ki-lti Horai, LamontDoherty Geological Observatory, Palisades, New York; Stanley Kling, Marine Life Research Group, Scripps Institution of Oceanography, La Jolla, California (present address: 416 Shore View Lane, Leucadia, California); Arend Meijer, Department of Geosciences, University of Arew Lane, Leucadia, California), Arend Meijer, Department of Gessciences, University of Arizona, Tucson, Arizona; Kazuaki Nakamura, Earthquake Research Institute, University of Tokyo, Tokyo, Japan; James H. Natland, Deep Sea Drilling Project, Scripps Institution of Oceanography, La Jolla California; Gordon H. Packham, Department of Geology and Geophysics, University of Sydney, Sydney, N.S.W. Australia; and Anatoly Sharaskin, Vernadsky Institute of Geochemistry, U.S.S.R. Academy of Sciences, Moscow, U.S.S.R.
}

Total core recovered $(\mathrm{m}): 36.68$

\section{Core recovery (\%): 37}

Oldest sediment cored:

Depth sub-bottom (m): 36.5

Nature: redeposited calcareous and vitric mud

Age: Pleistocene with reworked Cenozoic and Cretaceous fossils Measured velocity $(\mathrm{km} / \mathrm{s}): 1.59$

Principal results: Holes 460 and $\mathbf{4 6 0} \mathrm{A}-$ Site 460 is located in a small sediment pond deep on the inner (arc-side) wall of the Mariana Trench. Penetration was 85.0 meters with a 32 per cent core recovery rate at Hole 460 , and 99.5 meters with a recovery of 37 per cent at Hole 460A. The 76 meters of sediments cored at Hole 460 are Pleistocene diatomaceous ooze and siliceous mud, underlain by calcareous mud and vitric mud of Eocene to Oligocene age.

At Hole $460 \mathrm{~A}$, similar Pleistocene sediments are underlain by reworked sediments with a mixture of ages including all the Cenozoic and Cretaceous. The deepest sediments are early Miocene or late Oligocene conglomerates.

In both holes there are cobbles of basalts, altered basalts, and metabasalts in the sediments and possibly occurring as talus below them. The metabasalts contain amphibole and quartz but are not foliated. They thus resemble some amphibolite facies ocean-floor metabasalts.

\section{BACKGROUND AND OBJECTIVES}

Site 460 (SP-2B) is located deep on the inner (island arc-side) wall of the Mariana Trench (Fig.' 1). It is the third of the series (Fig. 2) of holes between the trench axis and the volcanic arc with background and objectives that were described in the chapter on Mariana forearc Background and Objectives. Only comments specifically appropriate to Site 460 will be discussed in this section.

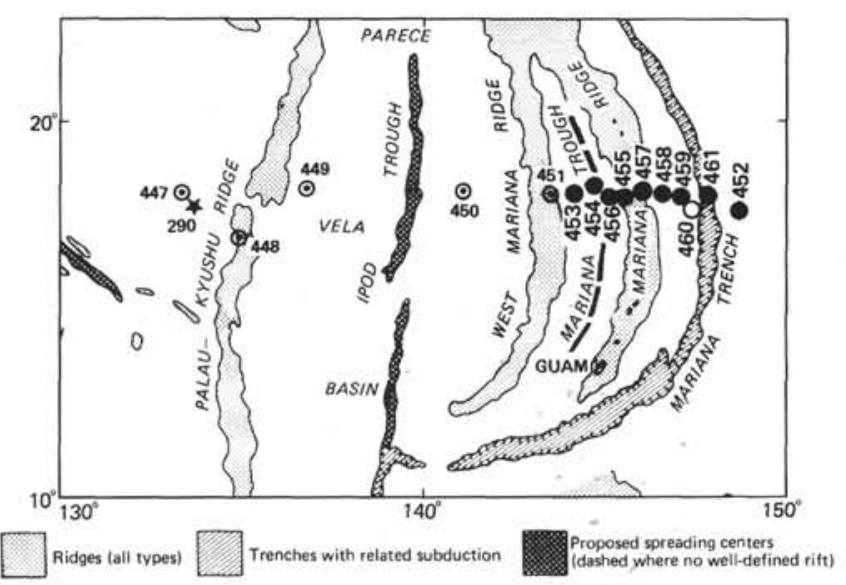

Figure 1. Location of Site $460(0)$ and the other sites drilled during Leg 60. 


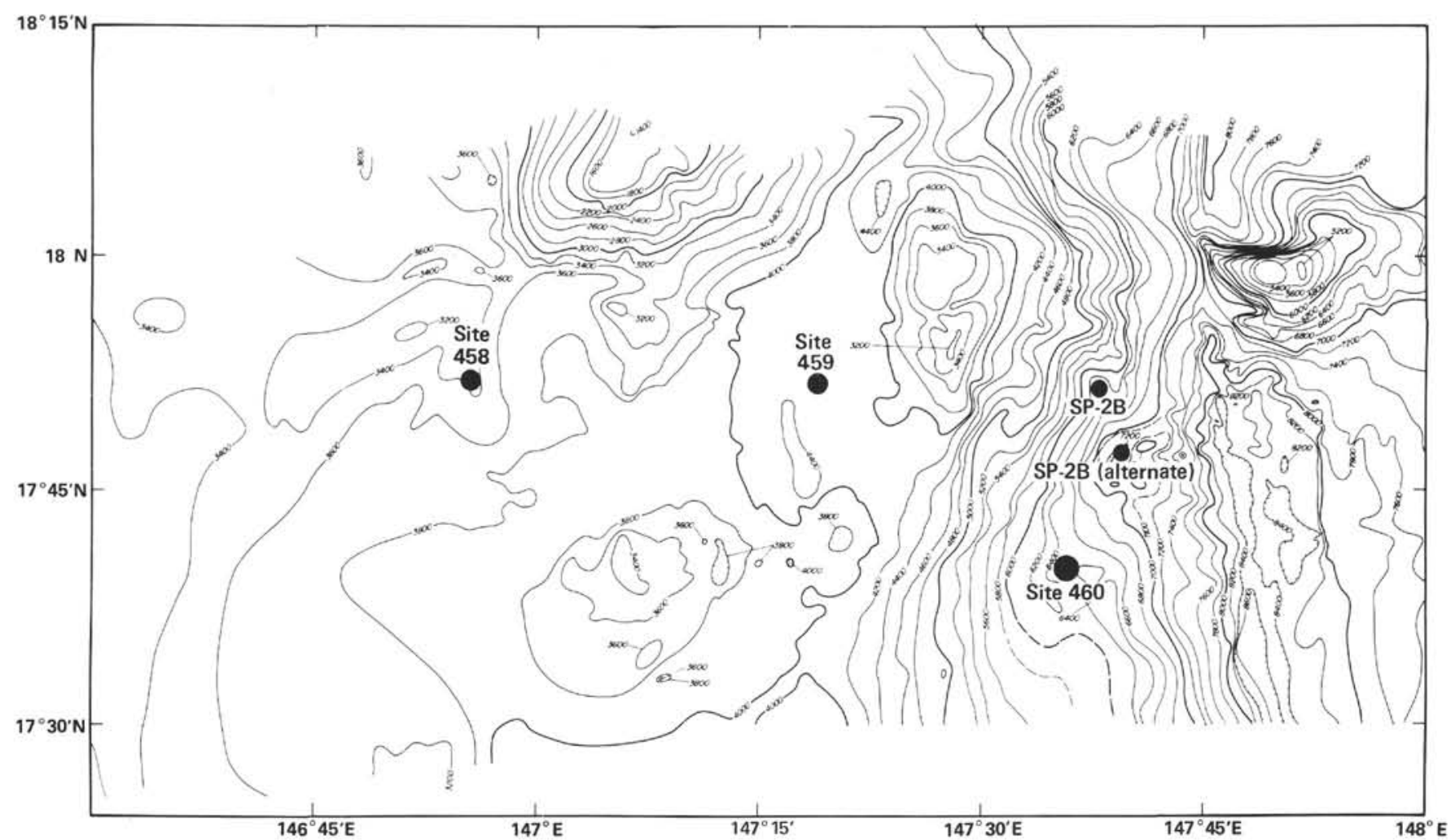

Figure 2. Bathymetry around the region of Site 460 . Contour intervals 200 meters (corrected).

There are a large number of geophysical profiles across the Mariana Trench, particularly near the $18^{\circ} \mathrm{N}$ transect region. A common observation of all these profiles is that there is very little sediment, either in ponds or draped down the slope, on the inner trench wall. There are also no sediments ponded in the trench axis. The single dominant criterion for selection of a drill site, therefore, was to locate sediment for spudding-in (attempting to touch down on what could be, based on the dredging in the area, a rock outcrop with a general $9^{\circ}$ slope, is considered hazardous to the drill string).

The site surveys located only three potential sediment ponds below a depth of 5500 meters on the trench wall (Hussong and Fryer, this volume) (Fig. 2):

1) $17^{\circ} 47.5^{\prime} \mathrm{N}, 147^{\circ} 39.0^{\prime} \mathrm{E}$ is a large pond with at least 200 meters of sediment, but it is at a water depth of over 7200 meters, which with the pipe string limit of 7427 meters would not provide enough useful penetration to satisfy the hole objectives;

2) $17^{\circ} 52.5^{\prime} \mathrm{N}, 147^{\circ} 38.0^{\prime} \mathrm{E}$ is at a depth of about 6300 meters, which is shallow enough to leave plenty of pipe for penetration, but is really only a re-entrant in the wall with relatively flat bottom where sediment might be located (an appreciable thickness of sediment was not actually observed during the site survey by the Hawaii Institute of Geophysics); and

3) $17^{\circ} 39.5^{\prime} \mathrm{N}, 147^{\circ} 35.0^{\prime} \mathrm{E}$ at a depth of 6460 meters, where one Hawaii Institite of Geophysics profile (Fig. 3) indicates some ponded sediment.
The second pond was chosen as SP-2B because it was closer to the center of the $18^{\circ} \mathrm{N}$ transect, and thus had more concentrated survey work in its vicinity. The third (southern) site was an alternative drill target, but was eventually chosen as Site 460 for logistical reasons that are described in the Operations section of this site report.

None of these trench wall sites has associated gravity or magnetic anomalies. Refraction data on the trench wall are unreliable because of the large topographic corrections required during interpretation, but they generally indicate velocities of slightly less than $4 \mathrm{~km} / \mathrm{s}$ for the first kilometer sub-bottom.

The primary objective of Site 460 is, of course, to determine the nature of the rocks and sediments that are in an almost completely unknown geologic environment. It has been speculated that the inner wall of the Mariana Trench could be almost anything from an accretionary wedge of upthrust oceanic crust material to an eroded margin of an old island arc. Based solely on the suite of rocks dredged off the trench wall, it is likely that it constitutes some combination of these two extreme models.

In addition to such general questions, this site warrants particular attention to clues as to its tectonic evolution, such as:

1) signs of excess water content in the section that might result from ocean-crust water percolating back up from the subducting slab; 


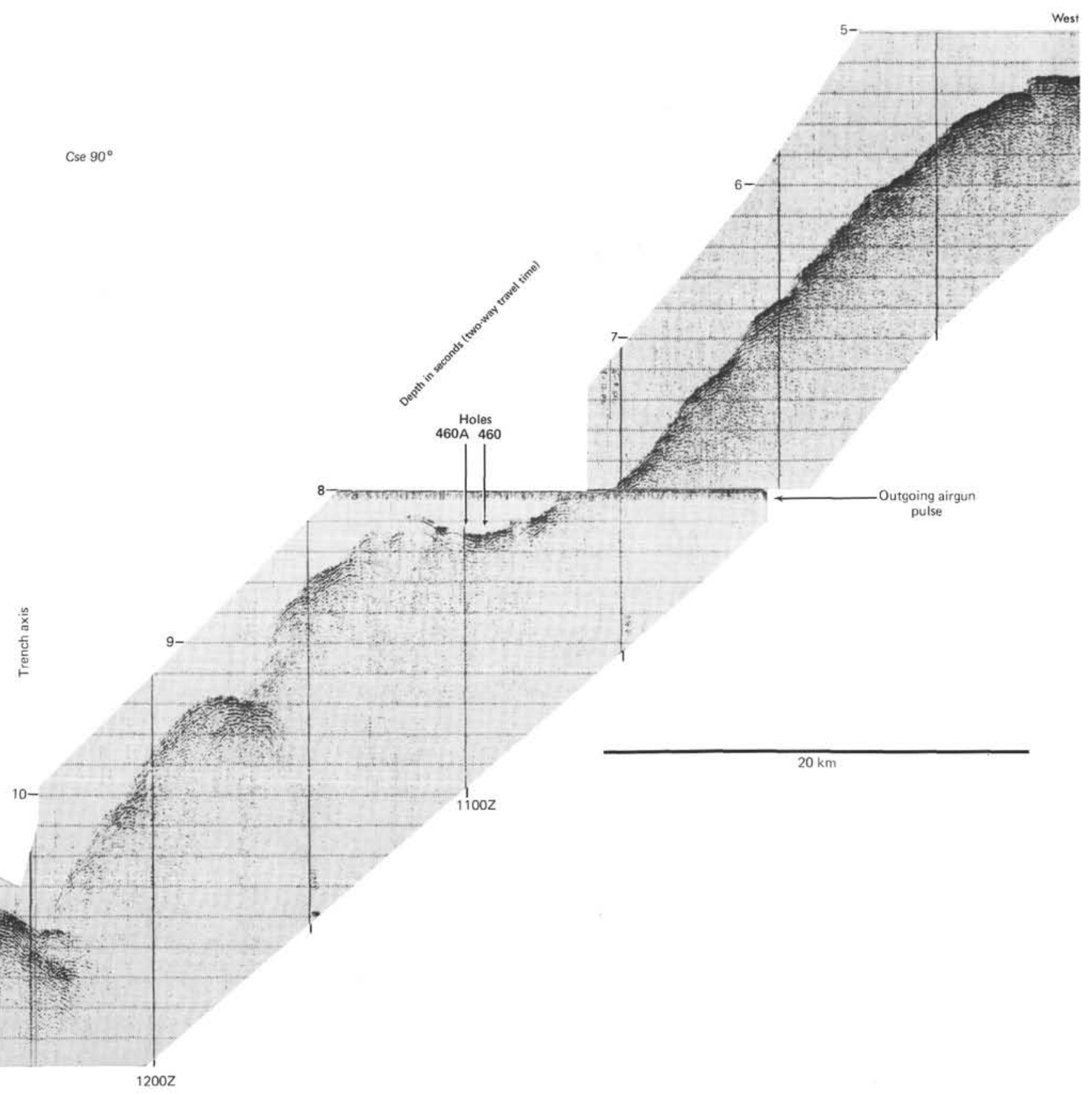


2) overpressuring of sediments, and indications of relatively high pressure metamorphism that would tell us the past depth of burial of recovered core material;

3) types and degree of fracturing of rocks and lithified sediments; and

4) repeated sections and other indications of various types of faulting and slumping.

\section{OPERATIONS}

Site 460 (SP-2B) was originally to have been located in a small re-entrant in the trench wall near $17^{\circ} 52.5^{\prime} \mathrm{N}$, $147^{\circ} 38.0^{\prime} \mathrm{E}$, at a depth of about 6300 meters. The site was chosen because site selection surveys had mapped the relatively flat bottom of the re-entrant, and the interpretation of a nearby multichannel seismic line indicated that there were sediments in the re-entrant. When we arrived at the site, however, we were unable to locate any sediments with either the $3.5-\mathrm{kHz}$ or the airgun reflection seismic system. The extremely long drill string that would be required at this site forced us to be particularly careful to find some sediments for spudding-in. After crisscrossing the area for several hours without finding sediments, this site was abandoned and we moved south to the alternative SP-2B target (see Background and Objectives section, this chapter). A sediment pond was located there (Fig. 4), and a $16-\mathrm{kHz}$, double-life beacon was dropped on the first pass over the pond (corrected depth from PDR: $6462 \mathrm{~m}$ ). The Challenger then made several additional passes over the area to determine the shape of the pond (which actually seems to be the head of a canyon feature in the trench wall). Based on these surveys, we offset to the center of the pond ( $1800 \mathrm{ft}$. west and $300 \mathrm{ft}$. south of the beacon) when the sediment thickness was estimated to be at least 30 meters (based on the $3.5-\mathrm{kHz}$ profile, Fig. 4). We rigged the standard 120-meter bottom-hole assembly with a $\mathrm{F} 93 \mathrm{CK}$ bit, and began running a pipe at 0006 local time on 5 May 1978. Spud-in was at 0953 local time in 6451.5 meters of water. The coring summary

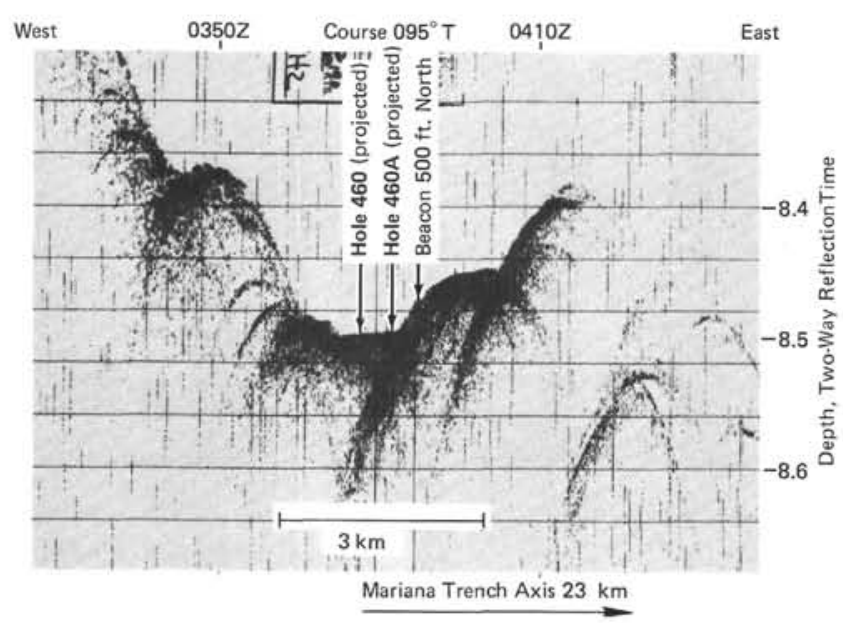

Figure 4. Portion of Glomar Challenger 3.5-kHz record over Site 460, showing sediments in a small pond on the arc-side trench wall of the Mariana Trench. The beacon location is indicated. and drilling rates are given in Table 1 and Figure 5A, respectively.

After the mudline core all cores required rotation, and by Core 6 (which was full of gravel) we were experiencing torquing of the drill string. After Core 6 (to $57 \mathrm{~m}$ sub-bottom), 20 barrels of mud were circulated in an attempt to clear the drill hole. This provided only temporary relief; Cores 7,8 , and 9 again took over 40 minutes each to cut, and torquing increased with each core. After Core 9 was retrieved, the bottom of the hole filled in 6 meters. When the bit was lowered, it had to be rotated for over an hour just to get to the top of the next coring interval. When trying to core what should have been the interval for Core 10, over an hour of rotation produced no penetration. The decision was then made to abandon the hole, and the drill string was pulled above the mudline. When the sandline was subsequently lowered to retrieve the core, we found that there was no core barrel in the drill string. Pumping tests then indicated no back pressure from the bit, so apparently some portion of the bottom-hole assembly and the inner barrel were gone. This was likely the cause of our inability to cut Core 10 .

The drill string was brought up and was aboard at 0000 on 6 May 1978. The bit had released by an apparent malfunction of the bit release sub-assembly.

The bottom-hole assembly was rebuilt (again as a standard 120-m system with a F93CK bit), the Challenger offset to the Site 460 beacon was changed to $950^{\prime} \mathrm{W}$ and $400^{\prime} \mathrm{S}$, and we started back down for Hole $460 \mathrm{~A}$ at 0345 local time on 6 May. It should be noted that even though we moved east from Hole 460 to Hole $460 \mathrm{~A}$, the satellite navigation positions for the two holes suggested that Hole $460 \mathrm{~A}$ is west of Hole 460 . This apparent inconsistency reflects the inaccuracy of the
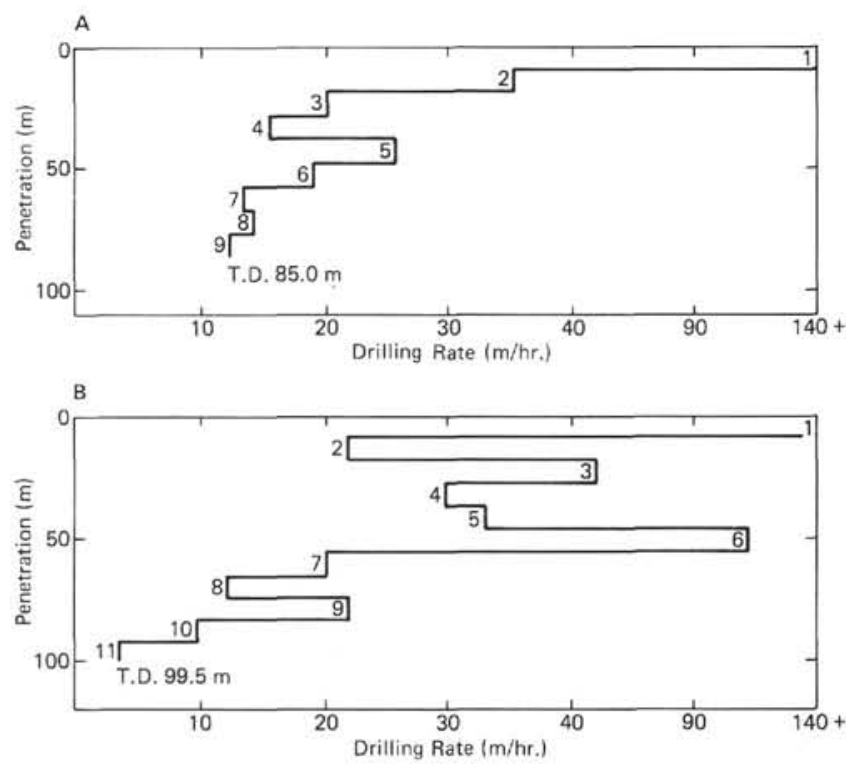

Figure 5. Drilling rates for (A) Hole 460 and (B) Hole 460A. T.D. = total depth (sub-bottom). Core numbers are shown on the figure. 
satellite navigation position; we were on site for a short time and received few fixes.

The corrected PDR depth at the second hole was 6455 meters. The spud-in depth (at 1549 local time) was 6453.5 meters, which is a depth of 6443.5 meters below the sea level. The coring summary and drilling rate are given in Table 1 and Figure 5B, respectively.

Drilling results at Hole $460 \mathrm{~A}$ were very similar to those at Hole 460; after Core 10 torquing and sticking became bad enough that 30 barrels of mud were spotted, but during the cutting of Core 11 the hole massively caved in causing the bottom-hole assembly to become completely stuck. When the string was worked loose, the hole was abandoned; Core 11 was retrieved after clearing the mudline.

As the bottom-hole assembly was brought up, it and the Bowen sub were magna-fluxed. This process took from 0400 to 1145 on 8 May. When the bit was brought on deck, an igneous rock (which we later found to be metabasalt) was found wedged very tightly in the core guide. The entire drill string was aboard and secured, and we departed for Site 461 at 1300 on 8 May 1978.

\section{LITHOLOGY}

\section{Hole 460}

In this hole, $76 \mathrm{~cm}$ of sediments were penetrated before reaching pieces of igneous rocks. In this short sequence, paleontological data show that a normal Paleogene sequence is overlain by a barren interval followed by Pleistocene (Fig. 6). Three lithostratigraphic units also can be seen in the sedimentary column.

\section{Unit I: 19 meters; 0-19 meters; Cores 1 and 2; Pleistocene}

The dominant lithology is light olive-gray and greenish gray, diatomaceous ooze, and siliceous mud associated with crystal mud and rare silty layers. Diatoms are very abundant, and associated with radiolarians, sponge

Table 1. Coring summary, Holes 460 and 460A.

\begin{tabular}{|c|c|c|c|c|c|c|c|}
\hline Core & $\begin{array}{l}\text { Date } \\
\text { (May } \\
\text { 1978) }\end{array}$ & Time & $\begin{array}{l}\text { Depth from } \\
\text { Drill Floor } \\
\text { (m) }\end{array}$ & $\begin{array}{l}\text { Depth below } \\
\text { Sea Floor } \\
\text { (m) }\end{array}$ & $\begin{array}{l}\text { Length } \\
\text { Cored } \\
\text { (m) }\end{array}$ & $\begin{array}{l}\text { Length } \\
\text { Recovered } \\
\text { (m) }\end{array}$ & $\begin{array}{c}\text { Recovery } \\
(\%)\end{array}$ \\
\hline \multicolumn{8}{|l|}{ Hole 460} \\
\hline 1 & 5 & 1125 & $6461.5-6471.0$ & $0-9.5$ & 9.5 & 6.81 & 71.7 \\
\hline 2 & 5 & 1342 & $6471.0-6480.5$ & $9.5-19.0$ & 9.5 & 0 & 0 \\
\hline 3 & 5 & 1621 & $6480.5-6490.0$ & $19.0-28.5$ & 9.5 & 6.96 & 73.2 \\
\hline 4 & 5 & 1844 & $6490.0-6499.5$ & $28.5-38.0$ & 9.5 & 8.03 & 84.5 \\
\hline 5 & 5 & 2101 & $6499.5-6509.0$ & $38.0-47.5$ & 9.5 & 0.62 & 6.5 \\
\hline 6 & 5 & 2323 & $6509.0-6518.5$ & $47.5-57.0$ & 9.5 & 1.90 & 20.0 \\
\hline 7 & 6 & 0226 & $6518.5-6528.0$ & $57.0-66.5$ & 9.5 & 1.26 & 13.3 \\
\hline 8 & 6 & 0453 & $6528.0-6537.5$ & $66.5-76.0$ & 9.5 & 1.51 & 15.9 \\
\hline 9 & 6 & 0740 & $6537.5-6546.5$ & $76.0-85.0$ & 9.0 & 0.12 & 1.3 \\
\hline Total & & & & & 85.0 & 27.21 & 32.0 \\
\hline \multicolumn{8}{|c|}{ Hole $460 \mathrm{~A}$} \\
\hline 1 & 7 & 1709 & $6453.5-6461.5$ & $0-8.0$ & 8.0 & 7.95 & 83.6 \\
\hline 2 & 7 & 1931 & $6461.5-6471.0$ & $8.0-17.5$ & 9.5 & 5.36 & 56.4 \\
\hline 3 & 7 & 2124 & $6471.0-6480.5$ & $17.5-27.0$ & 9.5 & 4.94 & 52.0 \\
\hline 4 & 7 & 2332 & $6480.5-6490.0$ & $27.0-36.5$ & 9.5 & 9.39 & 98.8 \\
\hline 5 & 8 & 0136 & $6490.0-6499.5$ & $36.5-46.0$ & 9.5 & 4.51 & 47.4 \\
\hline 6 & 8 & 0323 & $6499.5-6509.0$ & $46.0-55.5$ & 9.5 & 1.14 & 12.0 \\
\hline 7 & 8 & 0541 & $6509.0-6518.5$ & $55.5-65.0$ & 9.5 & 2.27 & 23.9 \\
\hline 8 & 8 & 0802 & $6518.5-6528.0$ & $65.0-74.5$ & 9.5 & 0.40 & 4.2 \\
\hline 9 & 8 & 1022 & $6528.0-6537.5$ & $74.5-84.0$ & 9.5 & 0.13 & 1.3 \\
\hline 10 & 8 & 1323 & $6537.5-6547.0$ & $84.0-93.5$ & 9.5 & 0.34 & 3.5 \\
\hline 11 & 8 & 1814 & $6547.0-6553.0$ & $93.5-99.5$ & 6.0 & 0.25 & 3.3 \\
\hline Total & & & & & 99.5 & 36.68 & 36.8 \\
\hline
\end{tabular}

spicules, and silicoflagellates. Clays (up to $50 \%$ ) contain zeolites and micronodules. Volcaniclastic materials are scarce $(\sim 5$ to $15 \%)$ but always represented. On the basis of radiolarian assemblages, Cores 1 and 2 are Pleistocene in age. Differentiation of zones is impossible due to scarcity of zone-diagnostic species. This unit is barren of nannofossils. It gave off a sulfurous odor when first split. It apparently was deposited under anoxic conditions deep in the Mariana Trench.

\section{Unit II: 9.5 meters, 19-28.5 meters; Core 3; Age: Undetermined}

This unit contains moderate brown crystal mud with gray patches of diatomaceous ooze and a few thin ash layers. Barren of nannofossils, this unit has diatoms and radiolarians, but no age-diagnostic assemblages were found.

Unit III: 47.5 meters; $28.5-76$ meters; Cores 4 through 9; Oligocene through Eocene

Dominant lithologies are: calcareous mud and crystal and vitric mud, interbedded with pebble layers (gravel and sand; Cores 5,6 , and 8 ) highly disturbed by drilling and strongly altered vitric ash. This unit ends with Sample 9,CC above two pieces of igneous rocks (see Igneous and Metamorphic Rocks section, this chapter). The reworked elements in sand and gravel up to $2 \mathrm{~cm}$ in diameter are subangular to subrounded pieces of lithified sediments (mudstone, siltstone, volcanic materials [rocks, scori]).

A thin section was made in a piece of sandstone from a pebble in Section 5-1. Reworked fragments in a clayey matrix are dominantly from volcanic sources, either volcanic rock fragments or altered glass and crystals. Several sedimentary rock fragments, including cherts and limestones, up to $2 \mathrm{~mm}$ in diameter, are also recognized in the thin section. Several limestone fragments appear to contain calpionellids (Tithonian-Barremian age). Chert fragments contain radiolarians. These fossil-bearing fragments appear to be reworked first as pebbles in a sandstone, and subsequently this sandstone was eroded out into pieces included in the Paleogene gravels.

Nannofossils and radiolarian assemblages give a good chronology in this unit: late Oligocene or older in Core 4 (nannofossils), early Oligocene in Core 5 (nannofossils and radiolarians), late Eocene in Core 6 (radiolarians), late or late middle Eocene in Core 7 (nannofossils), Eocene (unspecified) in Core 8 (radiolarians).

Severely altered and infilled radiolarians are reworked in the Eocene sediments (Cores 7 and 8, see Biostratigraphy section).

\section{Hole 460A}

About 75 meters of sediments were penetrated before encountering two pieces of igneous rock (Sample 9,CC) followed by gravel (Core 10) underlain by several pieces of "basalts" (Core 11). 


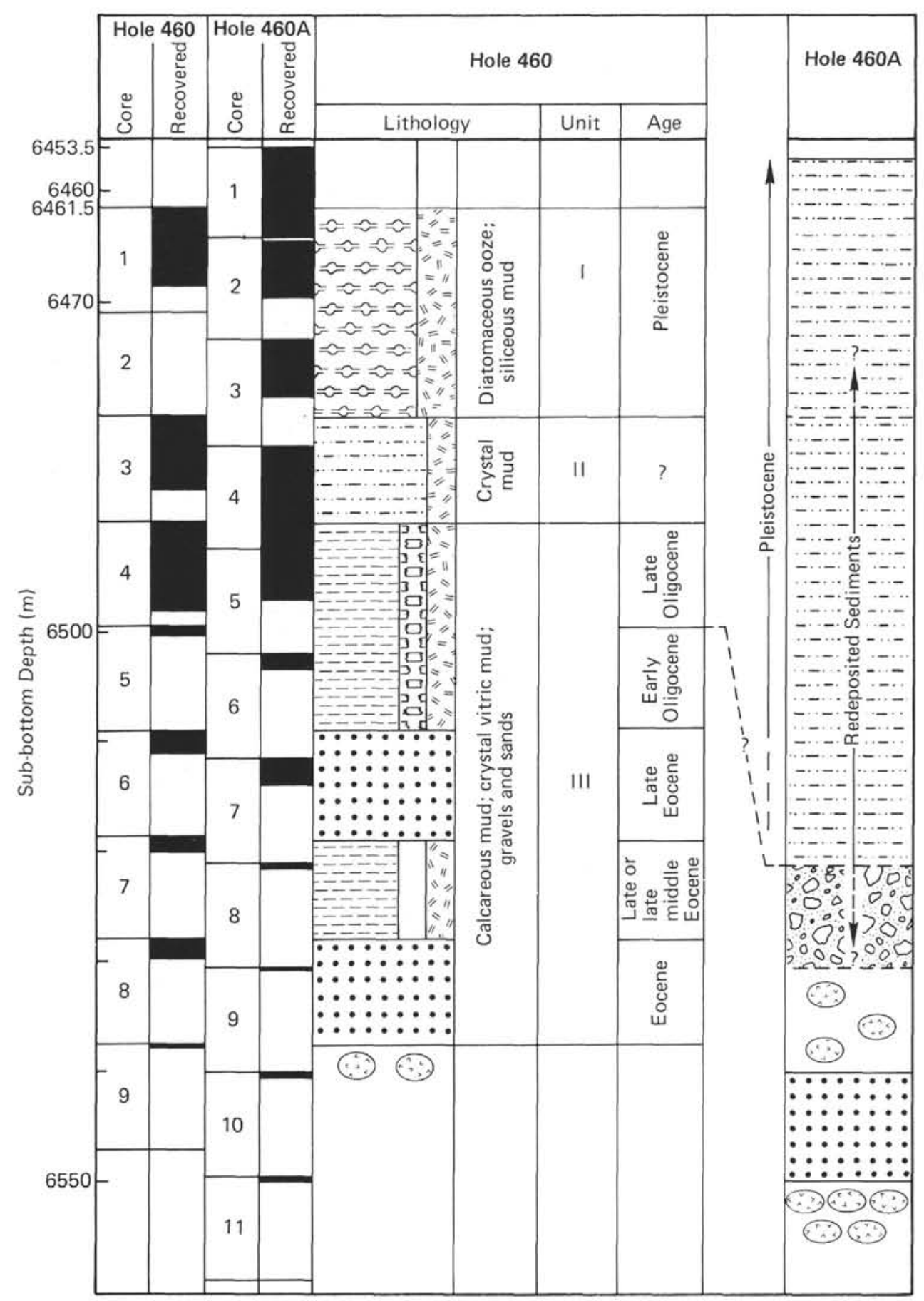

Figure 6. Summary lithology of and correlations between Holes 460 and 460A.

Compared with the lithology of Hole 460, there are some fundamental differences: the sequence is generally more strongly disturbed; dominant lithologies seen at Hole 460 are often mixed in Hole $460 \mathrm{~A}$ as shown by mixed colors (gray diatomaceous ooze and moderate brown mud). Original sedimentary structures are not identifiable. Reworked pebbles are more frequent. Calcareous mud is mixed with coarse sand.

Paleontological analysis definitively demonstrates that the major part (if not all) of the drilled sequence is strongly mixed and reworked (see Biostratigraphy and
Stratigraphic Synthesis, this chapter). The sedimentary sequence is divided into three units (Fig. 6):

\section{Unit I: 17.5 meters; 0-17.5 meters; Cores 1 and 2; Pleistocene}

Greenish gray diatomaceous ooze, brownish siliceous mud, and vitric mud are interbedded with occasional silty ash layers. This unit contains Pleistocene radiolarian assemblages. Its general characteristics are similar to those of Unit I of Hole 460. 
Unit II: $\mathbf{4 7 . 5}$ meters; $16.5-65$ meters; Cores 3 to 7

Paleontological data (based on both nannofossils and radiolarians) show that this unit contains only mixed sediments from all Cenozoic epochs (from Eocene through Pleistocene) and from Cretaceous (see Biostratigraphy section). This unit is composed entirely of redeposited sediments. This resedimentation occurred no earlier than Pleistocene at least until Core 4, as indicated by nannofossils (see Biostratigraphy section). Altered and infilled radiolarians similar to those from Hole 460 (Cores 7 and 8; Eocene) are found here in Cores 6 and 7.

\section{Unit III: 65 meters-74.5 meters; Sample 8,CC, Early Miocene or Late Oligocene}

This unit contains a conglomerate with granular aggregates and vesiculated fractured, altered, angular "basalt" fragments up to $7 \mathrm{~cm}$ in diameter, in a dusky yellow-green or light olive-gray clayey matrix. Grayish orange sediments occur sporadically. This conglomerate directly overlies pieces of igneous and metamorphic rocks (bottom of Sample 8,CC). In the clayey matrix just above the contact, traces of late Oligocene or early Miocene nannofossils were found. The possibility that these are the result of contamination or reworking cannot be excluded. Below the few basalt samples of Sample 9,CC, Sample 10,CC contains gravels consisting of subangular to subrounded moderately sorted fragments of volcanic rocks and claystones. The sequence ends with several pieces of basalt in Core 11 .

\section{BIOSTRATIGRAPHY}

\section{Summary}

The limited occurrences of radiolarians, supplemented by a few isolated occurrences of calcareous nannofossils, indicate the presence of Quaternary and older Tertiary sediments at Site 460 . The sequences, however, in the two closely spaced $(500-\mathrm{m})$ holes differ in detail.

In Hole 460, a normal sequence of middle or late Eocene through late Oligocene is overlain by a barren interval followed by Quaternary. In Hole 460A, a thoroughly mixed Cretaceous through Quaternary radiolarian and nannofossil assemblage is overlain by a Quaternary radiolarian assemblage.

No foraminifers were observed in samples from this site.

The presence of calcareous microfossils in deposits below the present Carbonate Compensation Depth (CCD) suggests rapid burial of material redeposited from shallower depths. This secondarily derived sediment in Hole 460A was deposited at its present location no earlier than Pleistocene.

The Cretaceous (approximately Campanian) radiolarians and nannofossils at this site represent the first Mesozoic occurrence recorded on the western side of the Mariana Trench. The nannofossils had to originate upslope, and the radiolarians, which occur as isolated specimens, probably did also. A rock fragment from
Hole 460 contains Calpionella alpina, an age-diagnostic planktonic microfossil from upper Tithonian-Berriasian (Azema and Blanchet, this volume). This is the first report of the Upper Jurassic microfossil in the western Pacific.

\section{Nannofossils}

The comparison of sporadic occurrences in samples from each hole indicates poor correlation between these two deep-water locations that are only 500 meters apart. Paleontologically productive levels present in one hole are apparently absent, or at least different, from those in the second hole.

In Hole 460, the following four samples contain poorly preserved nannofossils: Samples 4-1, $20 \mathrm{~cm}$; $5, \mathrm{CC} ; 7-1,7-8 \mathrm{~cm}$; and $7, \mathrm{CC}$. The assemblages contained in these samples indicate an age of late Oligocene or older, early Oligocene, late Eocene, and late or late-middle Eocene, respectively.

In Hole 460A, the following six samples contain nannofossils: Samples 4-3, $71 \mathrm{~cm}$; 4-3, 90-91 cm; 4-3, 124 $\mathrm{cm} ; 4-5,90-91 \mathrm{~cm} ; 4-6,90-91 \mathrm{~cm}$; and $4, \mathrm{CC}$. The highly diverse assemblage in Core 4 samples contains elements diagnostic of all Cenozoic epochs from Eocene through Pleistocene as well as Late Cretaceous.

\section{Radiolarians}

The two short holes drilled at Site 460 contain Quaternary radiolarian assemblages in fair abundance near the surface. Below that, sparse Tertiary assemblages occur. Holes 460 and $460 \mathrm{~A}$ contain, in addition, sparsely scattered Cretaceous radiolarians. The Cretaceous assemblages are variously preserved as both opal and microcrystalline quartz, indicating derivation from more than one source horizon.

In Hole 460, Cores 1 and 2 contain diverse Quaternary assemblages with the Buccinosphaera invaginata Zone recognizable in the upper part of Core 1 . Cores 3 and 4 are barren. Cores 5 through 8 contain low-diversity, generally poorly preserved assemblages dominated by Tristylospyris triceros, with Eocene species such as Dictyoprora mongolfieri and Lychnocanoma babylonis, indicating the latest Eocene Thyrsocyrtis bromia Zone. The appearance of older species (within the $T$. bromia Zone) in Cores 6 and 7 indicates a normal sequence in the radiolarian-bearing zone.

In Hole 460A, Cores 1 through 4 contain Quaternary assemblages with the Buccinosphaera invaginata Zone recognizable in the upper part of Core 1. Reworked early Oligocene occurs in Core 3 (CC) and reworked late Eocene in Core 4 (CC). Unzoned Quaternary assemblages occur in Core 5. Below Core 5, radiolarians are sparse and not clearly age-diagnostic.

Cretaceous radiolarians are scarce but consistently present in Hole 460, Core 1; and Hole 460A, Cores 2 through 5, where they are mixed with Quaternary sediment. If all the identifiable specimens are taken together, the approximately Campanian Amphipyndax enesseffi Zone can be recognized, but most of the species are undescribed and probably represent other ages (zones). 


\section{ACCUMULATION RATES}

Accumulation rates are estimated for Hole 460 by the same method as that used for previous sites-that is, from the radiolarian and nannofossil ages as plotted in Figure 7. Ages are determined from radiolarians for Cores 1, 2, 6, and 7, Section 1, and from calcareous nannofossils for Cores 4, 5, and 7,CC. Accumulation rates for the three lithologic units recognized in Hole 460 are as follows:

\begin{tabular}{|c|c|c|}
\hline Unit I: & Pleistocene (0-1.8 m.y.) & $>1.3 \mathrm{~kg} / \mathrm{cm}^{2} / \mathrm{m} . \mathrm{y}$. \\
\hline Unit II: & $\begin{array}{l}\text { A paleontologically bar- } \\
\text { ren interval between } \\
\text { Pleistocene and late } \\
\text { Oligocene (1.8- } 24 \text { m.y.) }\end{array}$ & $<0.06 \mathrm{~kg} / \mathrm{cm}^{2} / \mathrm{m} . \mathrm{y}$. \\
\hline Unit III: & $\begin{array}{l}\text { Late Oligocene through } \\
\text { middle Eocene ( } 24-42 \\
\text { m.y.) }\end{array}$ & $? 0.4 \mathrm{~kg} / \mathrm{cm}^{2} / \mathrm{m} . \mathrm{y}$. \\
\hline
\end{tabular}

The sedimentation rate for Pleistocene siliceous ooze and mud $\left(1.3 \mathrm{~kg} / \mathrm{cm}^{2} / \mathrm{m}\right.$.y. may be similar to that at Site $458\left(1.1 \mathrm{~kg} / \mathrm{cm}^{2} / \mathrm{m} . y\right.$.). From the sediment accumulation curve the rate at Site 459 is $2.0 \mathrm{~kg} / \mathrm{cm}^{2} / \mathrm{m}$.y.

The rate of $0.06 \mathrm{~kg} / \mathrm{cm}^{2} / \mathrm{m} . \mathrm{y}$. for Unit II assumes that the 9.4 meters of sediments in this unit were deposited during the entire interval between the Pleistocene and the late Oligocene. Such a low rate may not be uncommon for deep-sea sediments below the CCD, but a higher rate for much shorter time spans would be more realistic. Consequently, one or more hiatuses for this 20- to 25-m.y. interval should be suspected.'

The rate of $0.4 \mathrm{~kg} / \mathrm{cm}^{2} / \mathrm{m}$.y. for Unit III is one of the lowest rates observed during Leg 60 .

The accumulation rates for Hole $460 \mathrm{~A}$ are difficult to estimate with any certainty. The presence of large amounts of reworked sediments causes the rate during the Pleistocene to be significantly higher than it is at Hole 460.

\section{STRATIGRAPHIC SYNTHESIS}

Because of its normal undisturbed sequence, as shown by paleontological data and lithologic observations, sediments in Hole 460 probably represent normal Cenozoic sedimentation at this site. The lowest cored rocks are two pieces of basalt (Sample 9,CC) that could be either igneous basement or only pebbles reworked in the coarse overlying gravels (Core 8 ). The presence of interbedded pebbles of basalt between gravel and sand at Hole $460 \mathrm{~A}$ supports the latter hypothesis. This coarse detrital sand predates the late middle Eocene or late Eocene sediments from Core 7.

During the Eocene and Oligocene, a sequence of crystal vitric mud and calcareous mud was deposited. Occurrences of calcareous nannofossil assemblages in normal time succession and of carbonates within the mud, together with the absence of apparent disturbance, may indicate that these Paleogene sediments were first deposited above the $C C D$, which was probably considerably shallower than the present depth of the site (the eastern equatorial Pacific CCD paleodepths are thought to have been about 3400 meters during the Eocene and between 4.3 and $5 \mathrm{~km}$ from the Oligocene to the present day; van Andel et al., 1975).

After the late Oligocene, sediments are dominantly siliceous mud, rich in diatoms and radiolarians. A sequence of undetermined age (Core 3 ) is overlain by Pleistocene sediments (Cores 1 and 2). The absence of calcareous nannofossils, and of $\mathrm{CaCO}_{3}$ (based on carbonate bomb data) suggests sedimentation occurred below the CCD.

If so, the Site 460 area underwent considerable subsidence after the late Oligocene, from a former depth above the CCD during the Paleogene to the present location below the CCD (water depth-6451.5 m). A similar subsidence is also inferred at Site 459 (see site report for Site 459 , this volume).

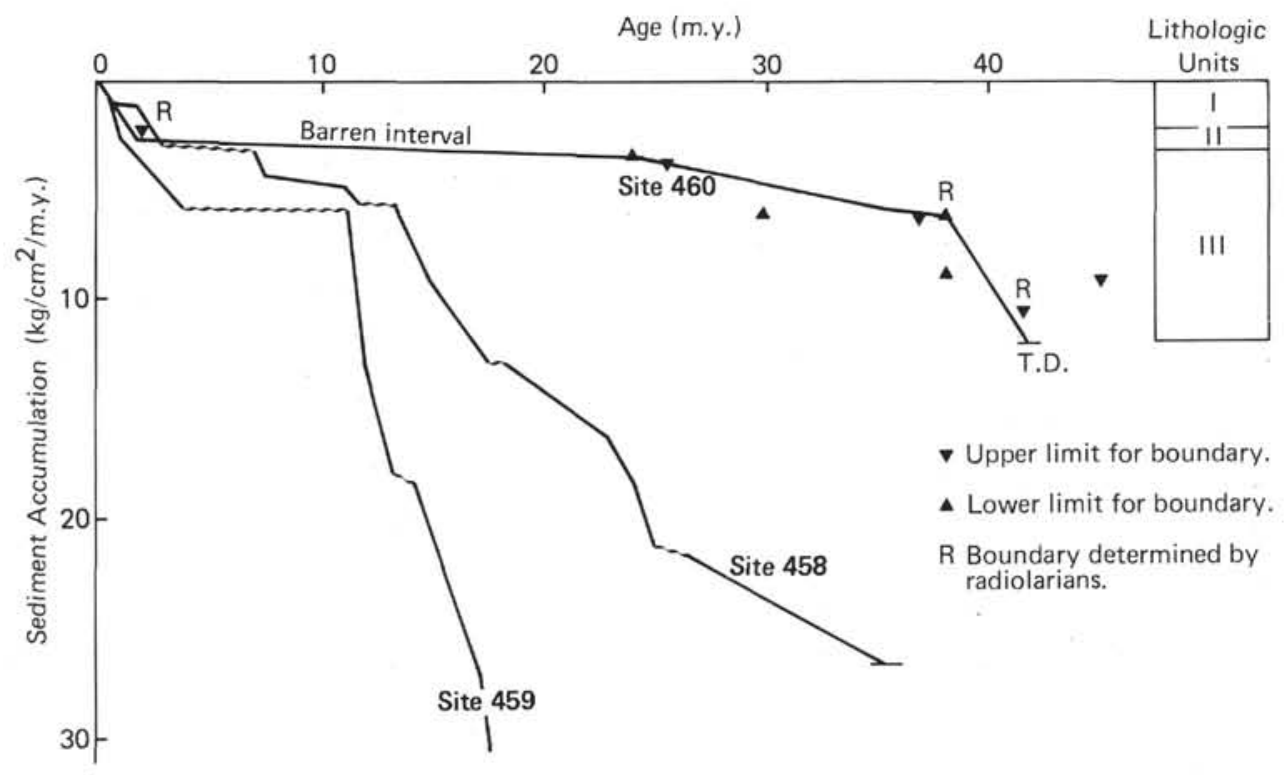

Figure 7. Sediment accumulation rates versus age at Site 460 , compared with Sites 458 and 459. 
The Cenozoic sequence at Site 460 shows very low accumulation rates (average $0.3 \mathrm{~kg} / \mathrm{cm}^{2} / \mathrm{m}$.y.), especially for the Neogene (see Accumulation Rates section). This can be partially explained by hiatuses which correlate with tectonically controlled subsidence. At other sites in the fore-arc and trench region (Sites 458 and 459) hiatuses also occur at various levels in the Cenozoic. For the Quaternary the accumulation rate is similar to that found at Site 452, which is also below the CCD on the Pacific plate.

Keeping in mind these remarks concerning Hole 460, tectonically controlled sedimentation during the Pliocene may explain the redeposited sequence drilled in Hole $460 \mathrm{~A}$. The $3.5-\mathrm{kHz}$ profile (Fig. 4) can be interpreted as showing normal faults east and west of this small basin in the lower slope of the trench (see Fig. 8).

A faulting event between the Oligocene and the Pleistocene created outcrops of the Cenozoic sequence and of pre-Eocene "basement." Cenozoic soft sediments were reworked and redeposited as talus at the foot of the fault scarp. Then, normal sedimentation (siliceous mud) covered these reworked Pleistocene sediments. Such rapid tectonically controlled deposition followed by immediate burial may explain how reworked Paleogene nannofossil assemblages can be deposited and preserved at a depth presently below the CCD.

The faulting event revealed by the stratigraphy in this small pond may be an episode of activity that is typical for the Cenozoic fore-arc and trench-wall tectonic regime. Reworked elements (mudstone, siltstone, volcanic materials, and mafic rocks; see Igneous and Metamorphic Rocks section) are encountered throughout the Cenozoic sequence. This general reworking of pre-
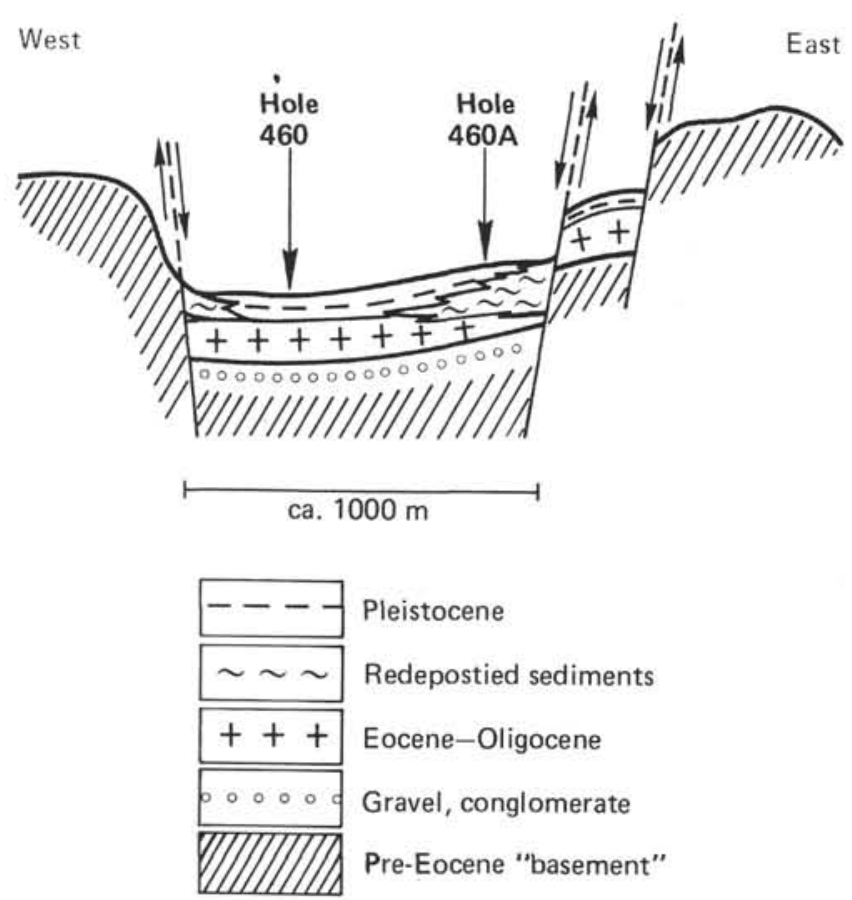

Figure 8. General topography and location of faults near Site 460 as interpreted from the seismic profile obtained by the Glomar Challenger (Fig. 4). Stratigraphy is inferred from the cores. existing rocks is particularly well established when agediagnostic assemblages are found, such as Upper Cretaceous radiolarians, or nannofossils from the Eocene, Oligocene, and Miocene and Pleistocene sediments.

\section{PORE WATER GEOCHEMISTRY}

Three samples were taken for pore water chemistry at Site $460-$ one in Hole 460 and two in Hole 460A. The data are given in Gieskes and Johnson (this volume).

Two samples, one each from Holes 460 and $460 \mathrm{~A}$, were taken at a depth of 6 meters below the sea floor. The sediments in both cases were clay-rich, gray mud that gave off a sulfurous odor when split in the core lab and which we interpret (see Lithology section, this chapter) as having been deposited under anoxic conditions deep in the Mariana Trench. The high sulfide content is reflected in the pore waters by high alkalinity. All other components are at levels similar to those of sea water.

The sample at 40 meters was taken from a brown crystal-vitric mud of Pleistocene age in Core 5. Cores above and below this interval contain reworked Paleogene and Neogene assemblages. The pore water sample from Core 5 is chemically similar to sea water, except for slightly higher $\mathrm{Ca}^{2+}$ and lower $\mathrm{Mg}^{2+}$.

\section{IGNEOUS AND METAMORPHIC ROCKS}

In both Holes 460 and $460 \mathrm{~A}$, cobbles of altered igneous rock were recovered within cores containing primarily sediments (vitric mud and ash), before the drill reached and was stopped by rubble or talus deposits of igneous and metamorphic rocks. In all, eight different types of igneous and metamorphic rocks from the two holes were sampled for thin sections. Undoubtedly other rock types were also recovered. The petrography of these eight rock types is presented below.

\section{Crystal-Vitric Tuffs} Samples 460A-5-1, 17-18 cm, and 460A-5-1, 24-25 cm;
Both Cobbles within Sediments

The rocks contain angular glassy fragments generally altered to clays and reddish iron oxides which cement the particles together. Lithic fragments $(0.1-0.5 \mathrm{~mm})$ comprise about 10 per cent of the rocks, and include subophitic basalt grains, vesicular glass grains, hyalopilitic plagioclase-clinopyroxene basalt grains, and palagonite grains. Broken crystals of plagioclase (3$5 \%)$, clinopyroxene $(1-3 \%)$, and quartz $(1 \%)$ are also present and are about the same size as the lithic grains. A fish tooth is present in Sample 5-1, 17-18 cm, as well as a few chert and limestone fragments. The rocks are probably lithified sediments derived from higher up on the trench wall.

\section{Clinopyroxene-Phyric Basalt}

\section{Sample 460-8-1, 148-150 cm; a Cobble within Sediments}

This rock, though altered, has a surprising resemblance to the spherulitic basaltic andesites of Site 458 (Unit III) which were associated with our "boninite se- 
ries" at that site. Acicular clinopyroxene microlites form about 5 per cent of the rock. A few clinopyroxene microphenocrysts also occur, but orthopyroxene phenocrysts are absent. Plagioclase is distinctly finer grained, occurring as needlelike crystals in spherulitic sworls. The rock contains abundant $(20 \%)$ small $(0.1-$ to $0.3-\mathrm{mm})$, irregular vesicles. The mesostasis between the plagioclase spherulites is altered to clays and reddish iron oxides. Clays also form thin linings in the vesicles.

\section{Sparsely Plagioclase-Clinopyroxene Phyric or Aphyric} Basalts Characterized by Plagioclase Microlites

\section{Samples 460-7,CC, 12-15 cm, and 460A-7,CC, $12-13 \mathrm{~cm}$; Both Cobbles in Sediments; and Samples 460A-9,CC, 6-3 cm and 460A-9,CC, $12-13 \mathrm{~cm}$; Two Rocks from the Breccia or Talus below the Sediments}

The rocks are hyalopilitic, with no more than 1 per cent plagioclase microphenocrysts and trace abundances of clinopyroxene microphenocrysts. Those from Sample $460 \mathrm{~A}-9, \mathrm{CC}$ are coarser grained and slightly less altered than the other two samples. Acicular plagioclase microlites between 0.1 and $0.5 \mathrm{~mm}$ long comprise between 5 and 20 per cent of the samples. Clinopyroxene occurs in the Core 9,CC samples as tiny acicular crystals largely replaced by clay. In the other samples, clinopyroxene, if once present, has been totally replaced by secondary minerals. The Core 9, CC samples contain fairly large (0.01- to $0.03-\mathrm{mm})$ skeletal or euhedral cubic opaque oxides. Vesicles are minor (0-5\%), small $(0.1-1 \mathrm{~mm})$, and irregular or round in shape.

The mesostasis is altered into two distinct types of material. About $40-45$ per cent of the sections consist of pale green, pale orange, or clear clays that are moderately birefringent and fairly crystalline. The clays appear to have replaced glass. The remainder of the mesostasis is orange-red in color and faintly birefringent, apparently an association of dispersed hydrous iron oxides and clays. Relict spherulitic texture can still be seen in these zones; these probably were clinopyroxenes which supplied the iron for the secondary hydrous iron oxides.

\section{Altered Hyaloclastite}

Samples 460A-8,CC, $35-37 \mathrm{~cm}$ at the Contact (Unconformity?) with Sediments Recovered in Core 8

The sample consists of angular, green altered glass fragments up to $5 \mathrm{~mm}$ in diameter, cemented in their own crushed glass matrix.

The extent of crystallinity of the fragments varies somewhat, but all are highly glassy (up to $84 \%$ glass). There are only about 1 per cent tabular plagioclase microphenocrysts $(0.1 \times 0.4 \mathrm{~mm})$ and even rarer clinopyroxene microphenocrysts. Both acicular plagioclase microlites (5\%, 0.0-0.2 mm long) and clinopyroxene microlites $(10 \%, 0.01-0.1 \mathrm{~mm}$ long) pervade the glass. Vesicles are rare $(2 \%)$, small $(0.2-0.4 \mathrm{~mm})$, and partially filled with clays and zeolites. Zeolites and clays also cement the glass fragments.
Because clinopyroxene microlites are so abundant, this rock does not appear to be related to the previously described hyalopilitic plagioclase basalts, even though some of the latter were recovered from Sample 9,CC (the interval just below this sample).

\section{Sparsely Plagioclase-Olivine-Clinopyroxene Phyric Basalt}

\section{Sample 460-9,CC, 4-76 cm; from Rubble or} Talus Zone at the Bottom of Hole $\mathbf{4 6 0}$

This is a hyalopilitic to spherulitic, sparsely phyric basalt with abundant $(\sim 20 \%)$ irregular vesicles. Microphenocrysts are euhedral plagioclase $(2 \% ; 0.1-0.4 \mathrm{~mm}$ long), clinopyroxene (trace, 0.1-0.3 mm long), and altered pseudomorphs after euhedral olivine (0.1-0.4 mm long). The olivines are completely altered to clays and $\mathrm{Fe}$ oxyhydroxides.

The groundmass consists of skeletal to acicular plagioclase $(15 \% ; 0.1-0.5 \mathrm{~mm}$ long) and abundant $(\sim 20 \%)$ spherulitic clinopyroxene. The mesostasis makes up about 40 per cent of the rock and is altered to clay and reddish oxyhydroxides. Clays line the vesicles.

\section{Quartz-Cemented Altered Basalt Breccia}

Sample 460A-10,CC, 25-27 cm; a Cobble in Basalt-Siltstone Drilling Breccia Recovered in Core $\mathbf{1 0}$

The thin section consists of one large basaltic fragment and several smaller, angular fragments, cemented by crystalline quartz in veins up to $0.5 \mathrm{~mm}$ wide. These veins also contain several per cent pyrite. Quartz is perhaps 40 per cent of the thin section, forming crystals in the veins $(0.05 \mathrm{~mm}$ in diameter $)$. It is also present as a secondary mineral in the groundmass of the basaltic fragments.

The fragments have similar textures; hence all are pieces of what was originally a single rock. They are aphyric, with about 5 per cent acicular plagioclase needles $0.1-0.2 \mathrm{~mm}$ long. The mesostasis, now almost entirely altered, carries abundant clay pseudomorphs after spherulitic clinopyroxene, and clays plus quartz after glass.

\section{Glassy Plagioclase-Clinopyroxene Phyric Basalt}

\section{Sample 460A-11-1, 25-26 cm; Pebble Among Metabasalts Recovered in Talus or Breccia at the Base of Hole 460A}

This was one of two glassy samples recovered in Core $460 \mathrm{~A}-11$, and the less glassy of the two; it was the only one from which a thin section was prepared. The texture is hyalopilitic. There are about 1 per cent each of microphenocrysts of plagioclase and clinopyroxene. The plagioclase tends to be tabular and is labradorite $\left(\mathrm{An}_{50-55}\right)$ in composition. The pyroxene is pale green and faintly plechroic.

The groundmass contains about 15 per cent of acicular to skeletal plagioclase (0.1-0.4 mm long), 5 per cent of acicular clinopyroxene (0.01-0.1 mm long), and 
traces of opaque oxides. There appear to be two types of plagioclase. One is the acicular variety just mentioned. In one or two places, this has grown in spoke-like arrays. The second type is less abundant; but where it occurs, it encloses the acicular feldspars. The crystals appear to be thin plates. Some have diamond-shaped cross sections. Some are only visible in crossed nicols as low first-order white feldspar. In plane light, all that can be seen of these is reddish brown glass and a thin outline of the crystal. Apparently, the crystal thickness is considerably less than the thickness of the thin section.

The glass is a rich, reddish brown color. Near vesicles, though, it is pale yellow in color, contains few crystals, and has a sharp boundary with the reddish brown glass. This yellow glass is faintly birefringent because of the presence of dispersed clays. It may be a type of poorly crystalline palagonite.

Vesicles are sparse (3-5\%), small $(0.1-0.5 \mathrm{~mm})$, and round or irregular in shape. All are surrounded by the yellow palagonite-like glass.

\section{Quartz-Amphibole-Plagioclase Metabasalts}

\section{Samples 460A-11-1, 29-31 cm and 460A-Center Bit; These are the Deepest Rocks Recovered in Hole 460A}

The rocks contain 50-60 per cent amphibole, yellowish green, and faintly pleochroic, $30-40$ per cent plagioclase, much of it relict from prior subophitic textures, and 7-10 per cent quartz, in patches between the feldspars and amphiboles. Traces of magnetite are present, as are those of relict clinopyroxene in the amphibole. The amphibole mantling these relict pyroxenes is crudely poikiloblastic, but foliation is absent.

The rocks originally were aphyric, but fairly coarse grained basalts. In hand specimens they appear quite fresh. Vesicles, if they were present, have been completely obliterated by metamorphism.

\section{Discussion}

Because of the wide variety of rock types recovered, and essentially no correlation at any level between the two holes drilled, we probably did not core into anything that can be defined as basement even though we penetrated well below the estimated 30 meters of sediment observed on the $3.5-\mathrm{kHz}$ profile (Fig. 4). The rock assemblage suggests that we bottomed in a talus (since we were deep in the trench) or some sort of breccia. The metabasalts appear to have been cored through an interval of perhaps 10 meters, and might have been a fairly large block of material.

The wide variety of rocks within the talus or breccia could have come from both arc and ocean-crust sources. The two samples that were chosen for land-based XRF study turned out to be chemically affiliated with arcderived rock types (Wood et al., this volume). The crystal-vitric tuffs and the clinopyroxene phyric basalt (which resembles some rocks from Site 458) also had an arc origin. The origin of some of the other altered basalts could have been either an arc-volcanic source, a portion of pre-arc oceanic basement, or former Pacific ocean crust incorporated into the inner trench wall dur- ing subduction. The metabasalts, which appear to have been metamorphosed to a facies transitional to amphibolite, but without foliation, in this respect resemble some oceanic metabasalts.

\section{Alteration and Metamorphism}

The petrographically different rock types recovered at Holes 460 and $460 \mathrm{~A}$ show variable degrees of alteration produced under diverse conditions. The quartzamphibole secondary mineral paragenesis observed in basalts and coarse-grained diabases from Hole 460A, Core 11, suggests the transformation of these rocks somewhere in between greenschist and amphibolite metamorphic facies. However, the original texture of the rocks remains unchanged (they are not foliated), indicating the rather high temperature but low-pressure metamorphic conditions.

The other rock cobbles and fragments contain mainly secondary clay minerals sometimes accompanied by zeolite or pyrite and quartz. Such mineral assemblages can be produced by both low-grade metamorphic and hydrothermal events. Additional geochemical data are needed to elucidate their origin. The diversity of rock alteration indicates a fairly complex composition and structure of the basement outcrops near the site.

\section{PHYSICAL PROPERTIES}

Compressional wave velocity, wet-bulk density, saltcorrected water content, porosity, and acoustic impedance were determined for cores recovered from Holes 460 and 460A. The results of measurements are presented in Table 2 . Thermal conductivity data are in Horai (this volume).

\section{SUMMARY AND CONCLUSIONS}

At Site 460 (survey target SP-2B), two closely spaced holes were drilled on the inner wall (island-arc side) of the Mariana Trench only $23 \mathrm{~km}$ from the trench axis. The site is about $\mathbf{2 2 0 0}$ meters shallower than the trench axis. The main objectives of drilling this site were to probe the basement of the sparsely sedimented deep trench wall to determine whether it consists of sediments or igneous rocks of oceanic or island-arc origin, and to see how these materials might have been emplaced in the trench wall.

The geophysical profiling indicated that the site was located in a small pond that is slightly over $1 \mathrm{~km}$ wide, had at least 30 meters of sediment, and was bounded on three sides by apparent normal fault blocks. The site appears to be the head of a canyon in the trench wall that starts on the north-east edge of the sediment pond. The sediment surface in the pond dips slightly to the west (toward the island arc).

Holes 460 and $460 \mathrm{~A}$ are separated by less than 300 meters, but the recovered sections have apparently had a substantially different history. Both holes failed to penetrate through an apparent talus rubble load composed of a wide variety of cobbles, including finegrained clinopyroxene-plagioclase basalts, metabasalts, altered crystal vitric tuffs, altered hyaloclastite, metadiabases, and plagioclase-free and pyroxene-rich, highly 
Table 2. Physical properties measurements, Holes 460 and 460A.

\begin{tabular}{|c|c|c|c|c|c|c|c|c|}
\hline $\begin{array}{c}\text { Sample } \\
\text { (interval in } \mathrm{cm} \text { ) }\end{array}$ & $\begin{array}{l}\text { Depth } \\
\text { (m) }\end{array}$ & $\begin{array}{c}\text { Sound } \\
\text { Velocity } \\
\text { (vertical) } \\
(\mathrm{km} / \mathrm{s})\end{array}$ & $\begin{array}{l}\text { GRAPE } \\
\text { 2-minute } \\
\text { Wet-Bulk } \\
\text { Density } \\
\left(\mathrm{g} / \mathrm{cm}^{3}\right)\end{array}$ & $\begin{array}{c}\text { Water } \\
\text { Content } \\
\text { (salt- } \\
\text { corrected) } \\
(\%)\end{array}$ & $\begin{array}{c}\text { Porosity }{ }^{a} \\
(\%)\end{array}$ & $\begin{array}{l}\text { Wet-Bulk }{ }^{b} \\
\text { Density } \\
\left(\mathrm{g} / \mathrm{cm}^{3}\right)\end{array}$ & $\begin{array}{c}\text { Acoustic } \\
\text { Impedance } \\
\left(\mathrm{g} / \mathrm{cm}^{2} \mathrm{~s} \times 10^{5}\right)\end{array}$ & $\begin{array}{l}\text { Rock } \\
\text { Type }\end{array}$ \\
\hline \multicolumn{9}{|l|}{ Hole 460} \\
\hline $1-1,40-42$ & 0.40 & 1.53 & & & & & & Soft mud \\
\hline $1-2,40-42$ & 1.90 & 1.51 & & 59.8 & 79.6 & 1.36 & 2.05 & Mud \\
\hline $1-3,30-32$ & 3.30 & 1.53 & & & & & & Mud \\
\hline $1-4,39-41$ & 4.89 & 1.51 & & 58.4 & 78.9 & 1.38 & 2.08 & Mud \\
\hline $3-1,96-98$ & 19.96 & 1.57 & & 54.6 & 76.2 & 1.43 & 2.25 & Mud \\
\hline $3 \cdot 2,80-82$ & 21.30 & 1.54 & & & & & & Mud \\
\hline $3-3,75-77$ & 22.75 & 1.55 & & 52.52 & 74.35 & 1.45 & 2.25 & Mud \\
\hline $3-4,40-42$ & 23.90 & 1.54 & & & & & & Mud \\
\hline $4-1,22-24$ & 28.72 & 1.56 & & 39.3 & 63.8 & 1.66 & 2.59 & \\
\hline $4-2,23-25$ & 30.23 & 1.57 & & & & & & \\
\hline $4-3,79-81$ & 32.29 & 1.53 & & 54.0 & 75.9 & 1.44 & 2.20 & \\
\hline $4-4,43-45$ & 33.43 & 1.55 & 1.43 & 55.9 & 77.4 & 1.42 & 2.20 & Firm mud \\
\hline $4-5,95-97$ & 35.45 & 1.55 & 1.47 & 55.8 & 77.5 & 1.42 & 2.20 & Firm mud \\
\hline $7-1,58-60$ & 57.58 & 1.57 & 1.50 & 47.9 & 70.3 & 1.51 & 2.37 & Soft mud \\
\hline SP2-0, 29-31 & & 1.54 & & & & & & Soft mud \\
\hline SP2-1, 55-57 & & 1.52 & & 51.5 & 73.7 & 1.47 & 2.23 & Ooze \\
\hline SP2-2, 58-60 & & 1.54 & & 50.2 & 73.0 & 1.49 & 2.29 & Mud \\
\hline SP2-3, 80-82 & & 1.53 & & 48.8 & 71.6 & 1.50 & 2.30 & Firm mud \\
\hline SP2 $-5,35-37$ & & 1.52 & & 49.4 & 72.0 & 1.49 & 2.26 & Firm mud \\
\hline \multicolumn{9}{|l|}{ Hole $460 \mathrm{~A}$} \\
\hline $1-1,53-55$ & 0.53 & 1.57 & & & & & & Ooze \\
\hline $1-2,40-42$ & 1.90 & 1.54 & & & & & & Ooze \\
\hline $1-3,53-55$ & 3.53 & 1.53 & & & & & & Ooze \\
\hline $1-4,55-57$ & 5.05 & 1.52 & & 64.1 & 82.4 & 1.32 & 2.01 & Ooze \\
\hline $1-5,94-96$ & 6.94 & 1.54 & & & & & & Ooze \\
\hline $2-1,99-101$ & 8.99 & 1.54 & & & & & & Ooze \\
\hline $3-2,74-76$ & 12.74 & 1.54 & 1.48 & 55.7 & 77.3 & 1.42 & 2.19 & Firm mud \\
\hline $3-3,74-76$ & 21.24 & 1.53 & 1.50 & 59.1 & 78.7 & 1.37 & 2.10 & Ooze \\
\hline $3-4,25-27$ & 22.25 & 1.53 & 1.53 & & & & 2.34 & Firm mud \\
\hline $4-1,126-128$ & 28.26 & 1.57 & 1.73 & 46.4 & 70.3 & 1.55 & 2.43 & Mud \\
\hline $4-2,85-87$ & 29.35 & 1.56 & 1.74 & & & & 2.71 & Firm mud \\
\hline $4-4,77-79$ & 32.27 & 1.56 & 1.73 & 38.7 & 63.1 & 1.67 & 2.61 & Firm mud \\
\hline $4-5,60-62$ & 33.60 & 1.59 & 1.86 & & & & 2.96 & Firm mud \\
\hline $4-6,82-84$ & 35.32 & 1.54 & 1.75 & 41.6 & 66.2 & 1.63 & 2.51 & Mud \\
\hline $5-1,58-60$ & 37.08 & 1.60 & & & & & & Sand \\
\hline $5-2,65-67$ & 38.65 & 1.54 & 1.52 & 51.2 & 73.7 & 1.48 & 2.28 & Stiff mud \\
\hline $5-3,75-77$ & 40.25 & 1.60 & 1.70 & 41.1 & 64.7 & 1.61 & 2.58 & Stiff mud \\
\hline $6-1,75-77$ & 46.75 & 1.55 & & & & & & Mud \\
\hline $6-2,81-83$ & 46.81 & 1.54 & 1.52 & 51.5 & 74.0 & 1.47 & 2.26 & Mud \\
\hline $7-1,108-110$ & 56.58 & 1.59 & 1.60 & 44.9 & 68.9 & 1.56 & 2.48 & Mud \\
\hline $9, \mathrm{CC}, 13-15$ & & 3.21 & 2.09 & & & & 6.71 & Basalt \\
\hline
\end{tabular}

a Porosity $=$ salt-corrected water content $\times$ wet-bulk density (gravimetric) $/ 1.025$.

$\mathrm{b}$ Gravimetric method.

vesicular basaltic andesites (boninite?). The metabasalts contain amphibole and quartz but are not foliated. These rocks include some which definitely are related to arc and fore-arc basement cored at Sites 458 and 459, but could also include some derived from oceanic crust. Geochemical analysis of two samples from the talus or rubble, as well as a sample from within the overlying sediments, showed that they all had island-arc affinities (Saunders et al., 1978; Wood, this volume).

The igneous rubble began at a depth of $\sim 75$ meters below the sea floor in both holes. The chaotic nature of the igneous sections leads us to believe that none of these samples is likely to represent in situ basement.

The igneous rubble in Hole $460 \mathrm{~A}$ is overlain by a 9.5-meter layer of very slowly deposited Miocene or late Oligocene conglomerate. This in turn is overlain by 47.5 meters of reworked sediments that contain mixed fossils from all Cenozoic and Cretaceous ages which were apparently redeposited in earlier than Pleistocene.

In contrast, above the igneous rubble in Hole 460 we found a 47.5-meter late or middle Eocene to late Oligocene sequence that, based on paleontological data and lithologic observations, is an undisturbed section of Cenozoic sediments. However, the occurrence of apparently undisturbed carbonates and a normal time suc- cession of calcareous nannofossils in the section indicates that they were deposited above the CCD. Since the $\mathrm{CCD}$ has, from before Eocene to present, apparently been much shallower than the depth of 6500 meters where these calcareous sediments are found, we conclude that the Eocene-Oligocene section has subsided since deposition. This subsidence had to have occurred in a sufficiently large block to leave the sequence undisturbed, but does not seem to have included the sampled sediments that are 300 meters away in Hole 460A.

Above the subsided Eocene-Oligocene section, a barren crystal mud estimated to be 9.5 meters thick underlies 19 meters of Pleistocene diatomaceous ooze and siliceous mud in Hole 460. This Pleistocene section is of about the same thickness in both holes at Site 460, and has a slow sedimentation rate and a lithologic character reminiscent of the uppermost sediments at Site 452, which is across the trench and about $100 \mathrm{~km}$ to the east, on the Pacific plate at a depth of 5860 meters.

Thus we infer that some time between the Oligocene and the Pleistocene, Site 460 was subject to major faulting and subsidence. These events displaced the undisturbed Eocene-Oligocene sequence at Hole 460 well below the CCD, and created outcrops of this sequence 
and pre-Eocene sediments, fragments of which were reworked and redeposited at Hole 460A. The redeposition at Hole $460 \mathrm{~A}$ had to be rapid enough to bury the reworked calcareous nannofossils before dissolution if it occurred at the present depth, or it occurred above the CCD prior to subsidence.

\section{REFERENCES}

Saunders, A. D., Marsh, N. G., and Tarney, J., 1978. Geochemistry of arc and inter-arc basalts from the east Mariana transect: IPOD Leg 60. EOS, 59:1182.

van Andel, Tj. H., 1975. Mesozoic/Cenozoic calcite compensation depth and the global distribution of calcareous sediments. Earth Planet. Sci. Lett., 26:187-194. 

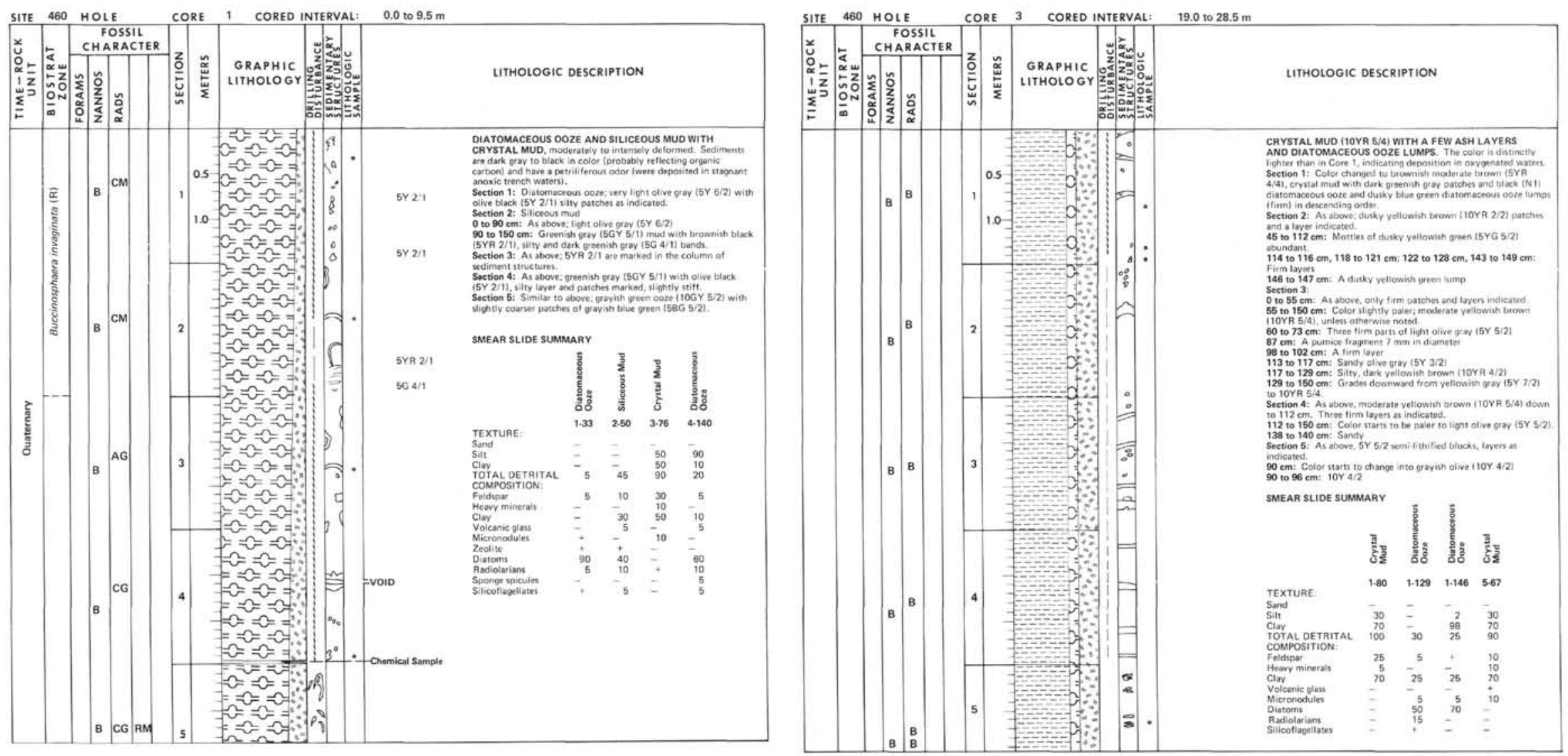

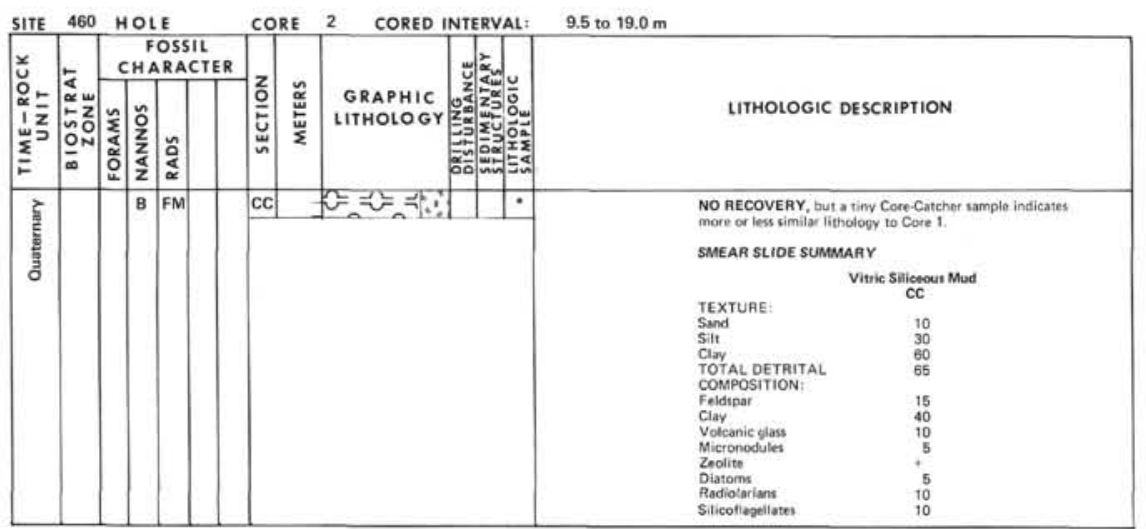




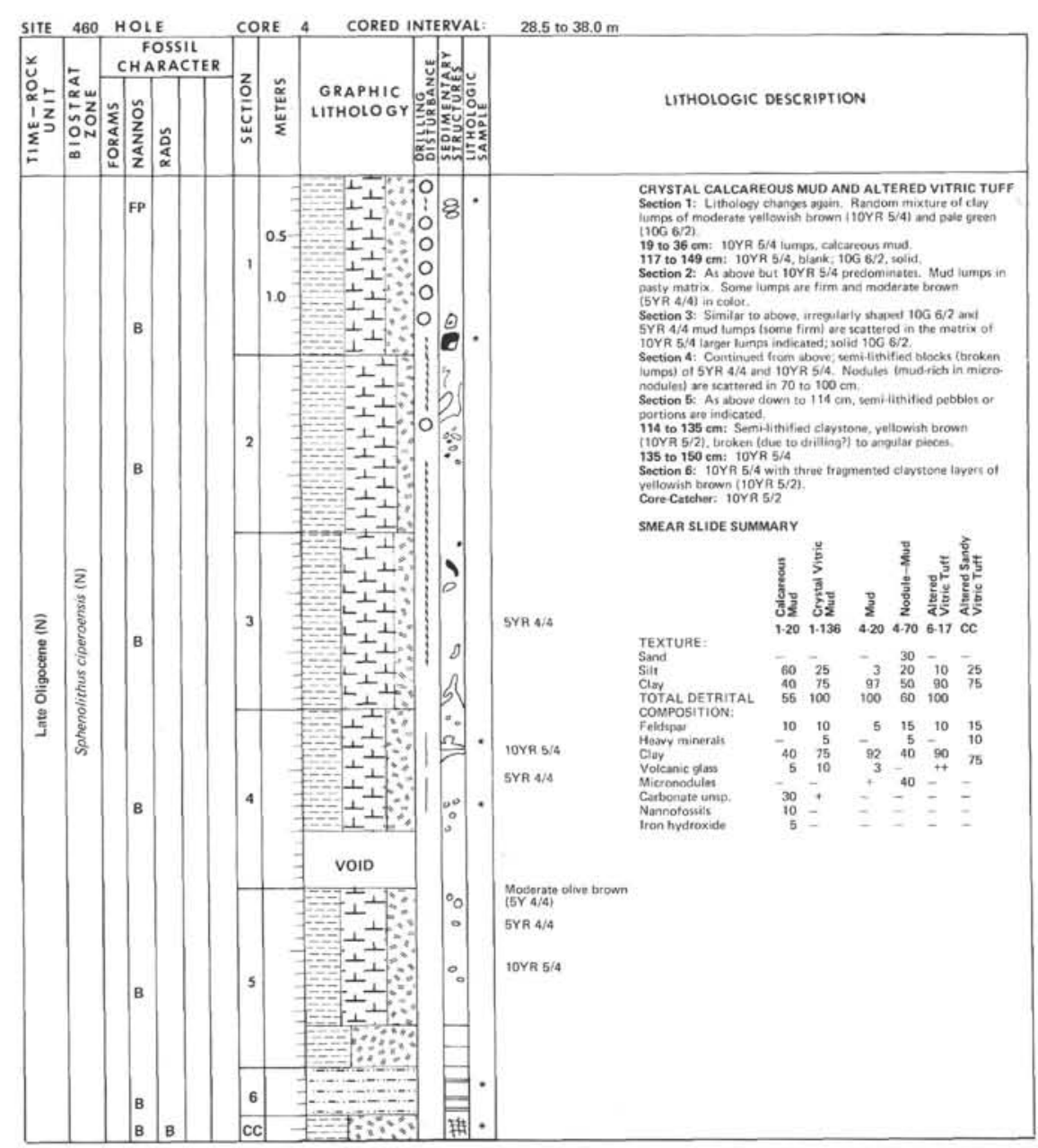

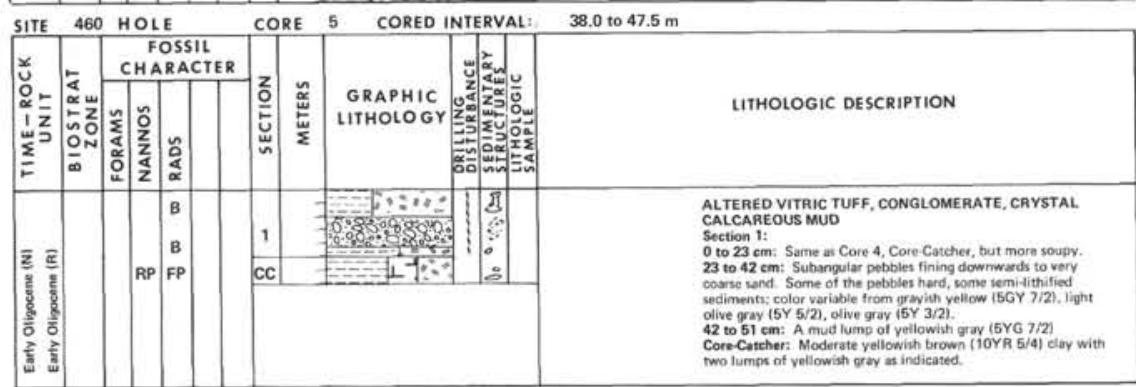

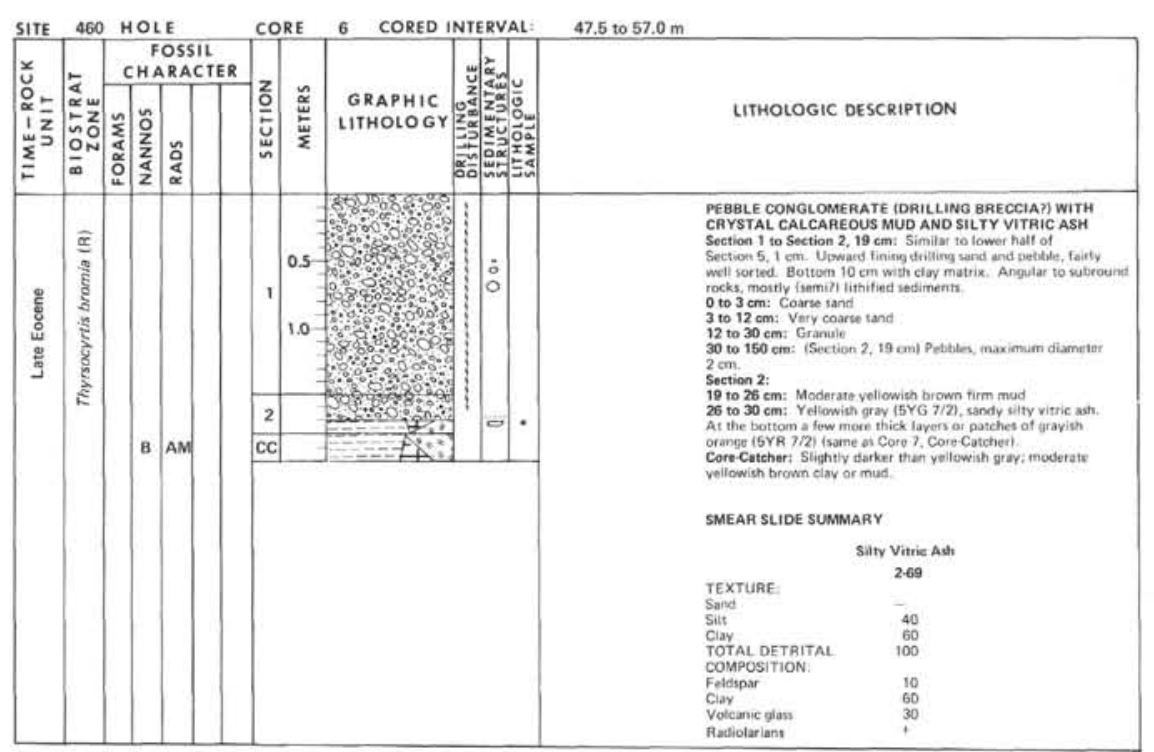

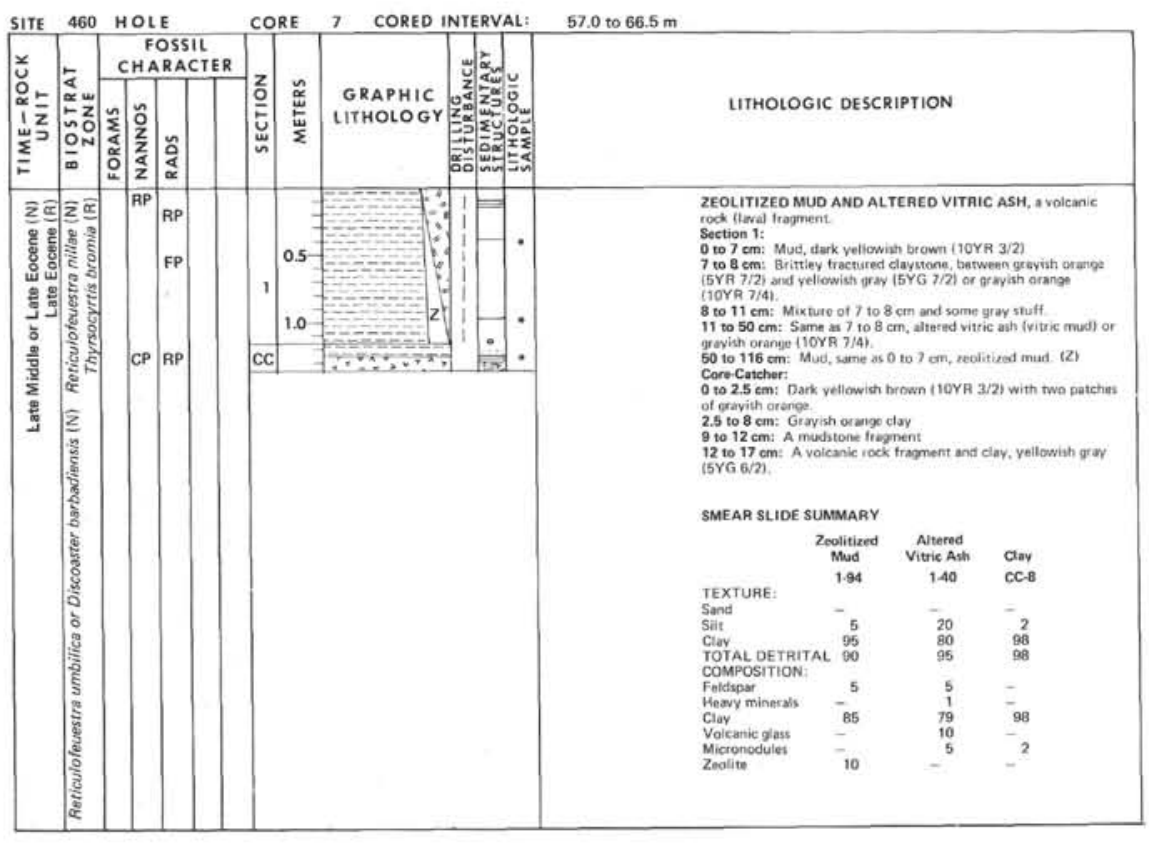



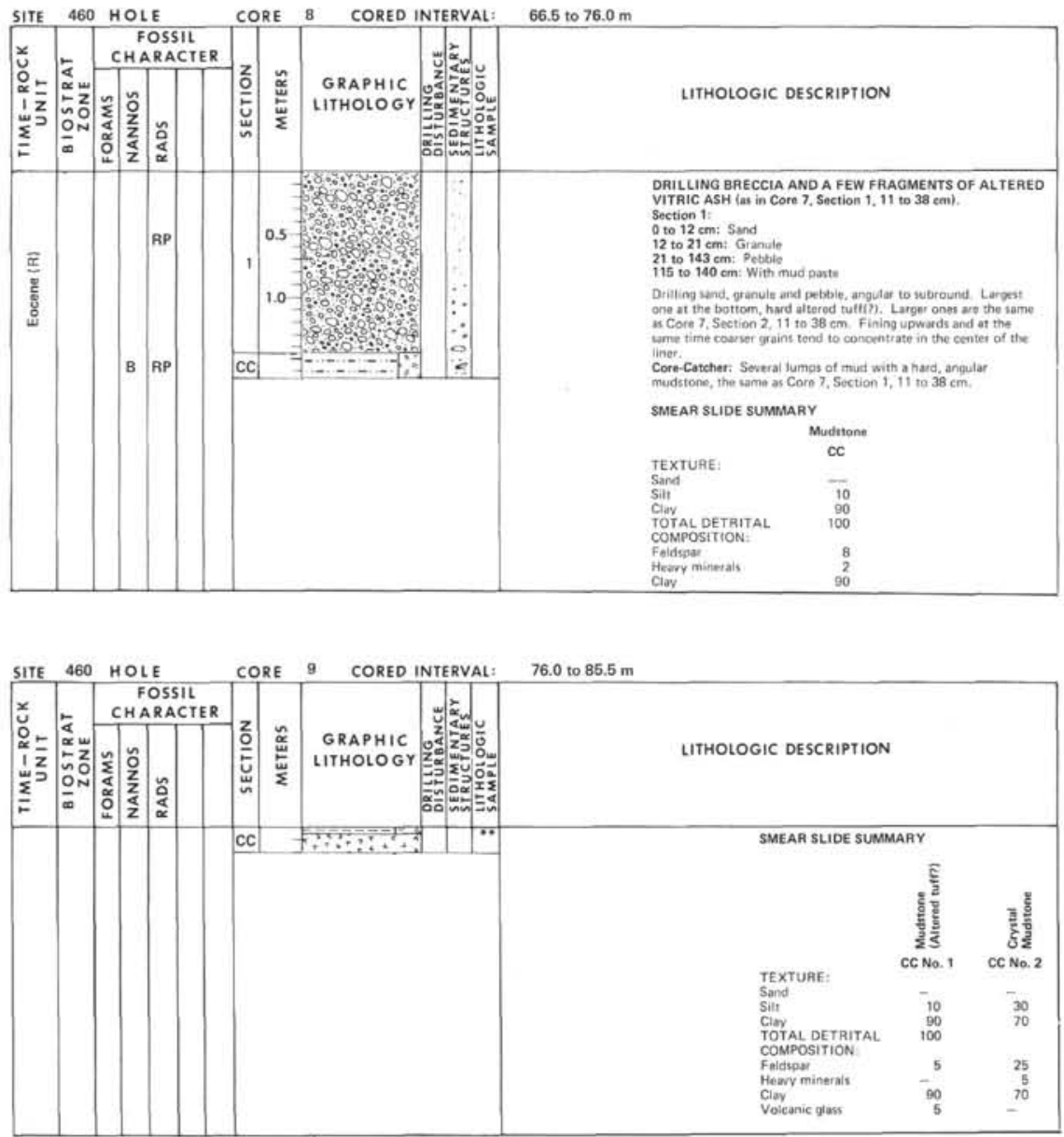

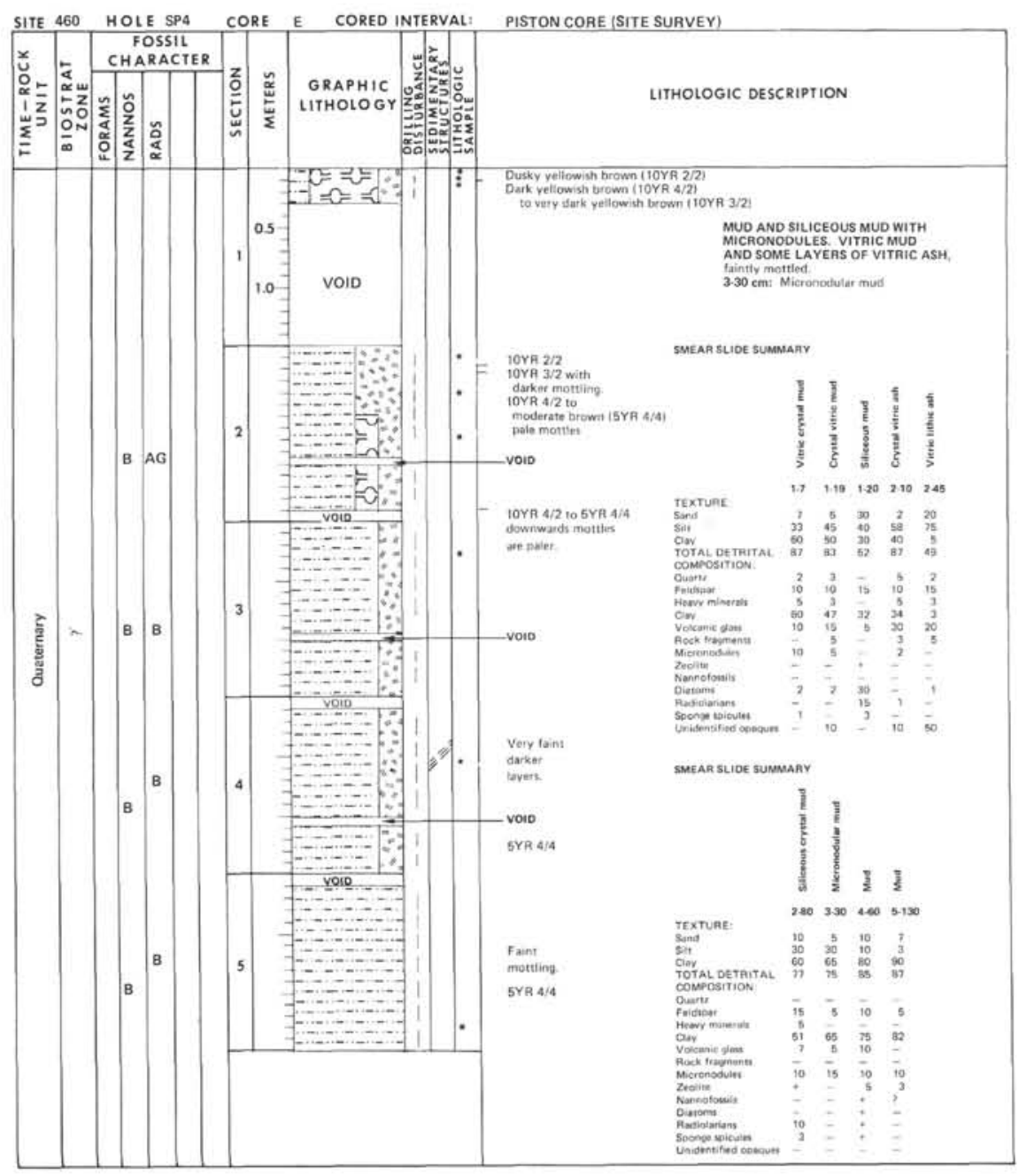




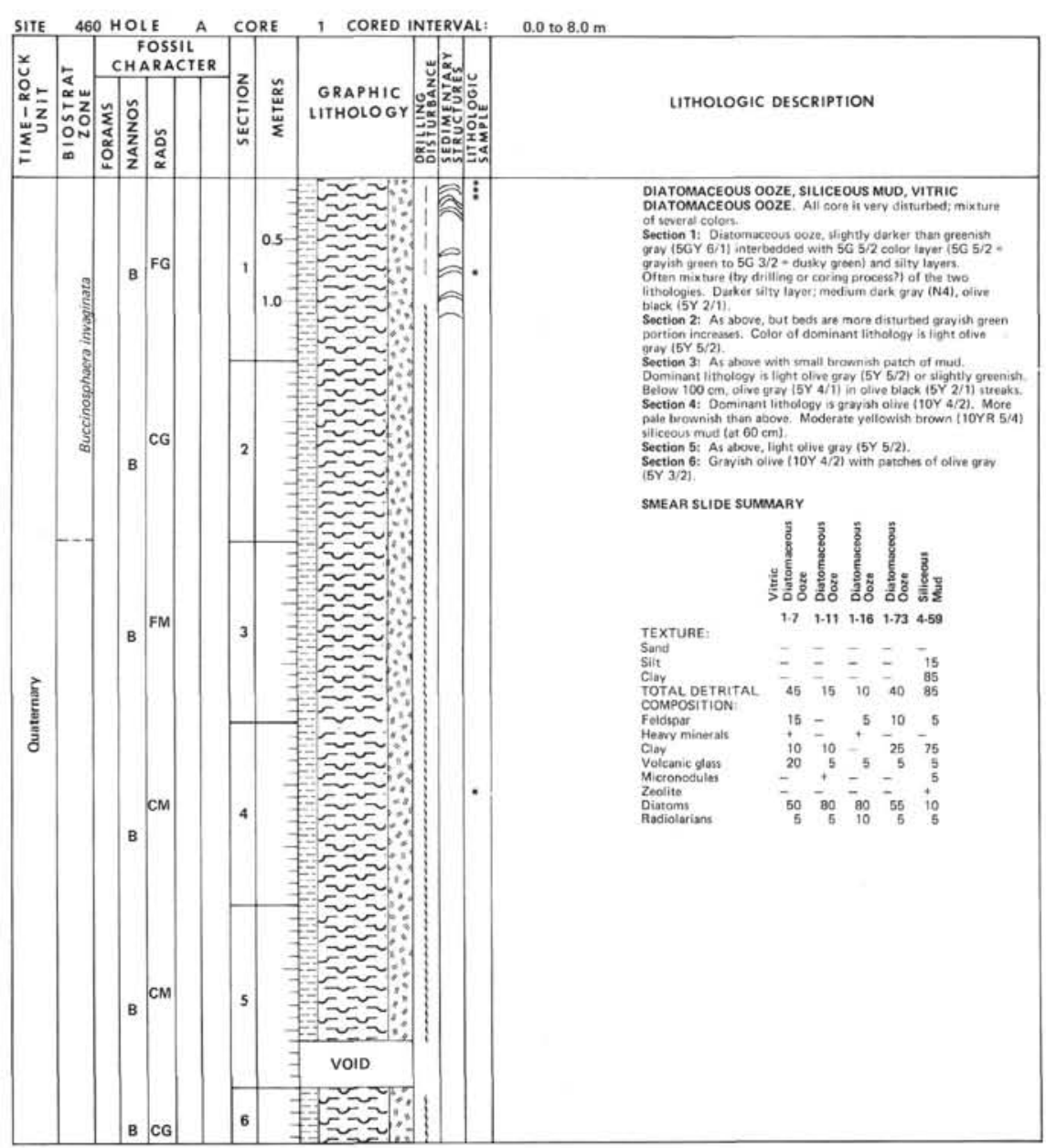

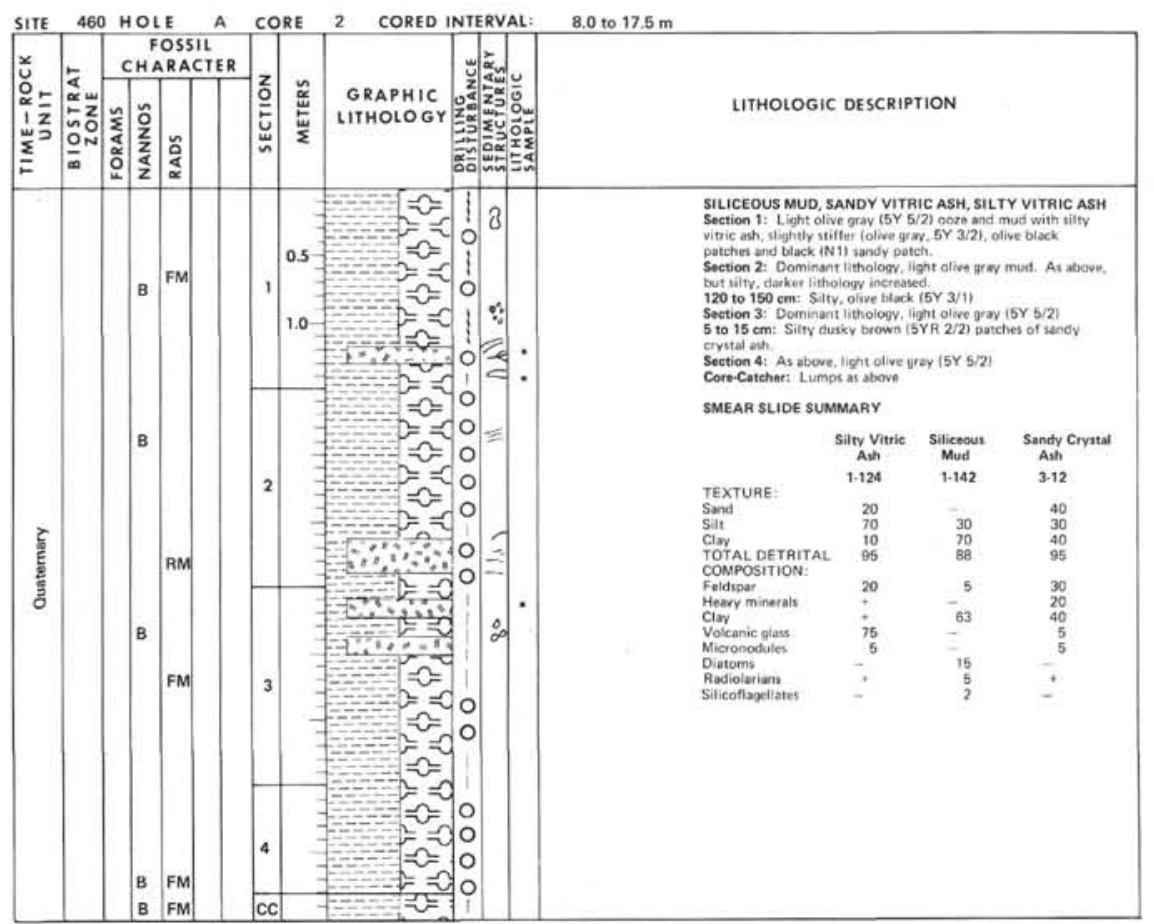



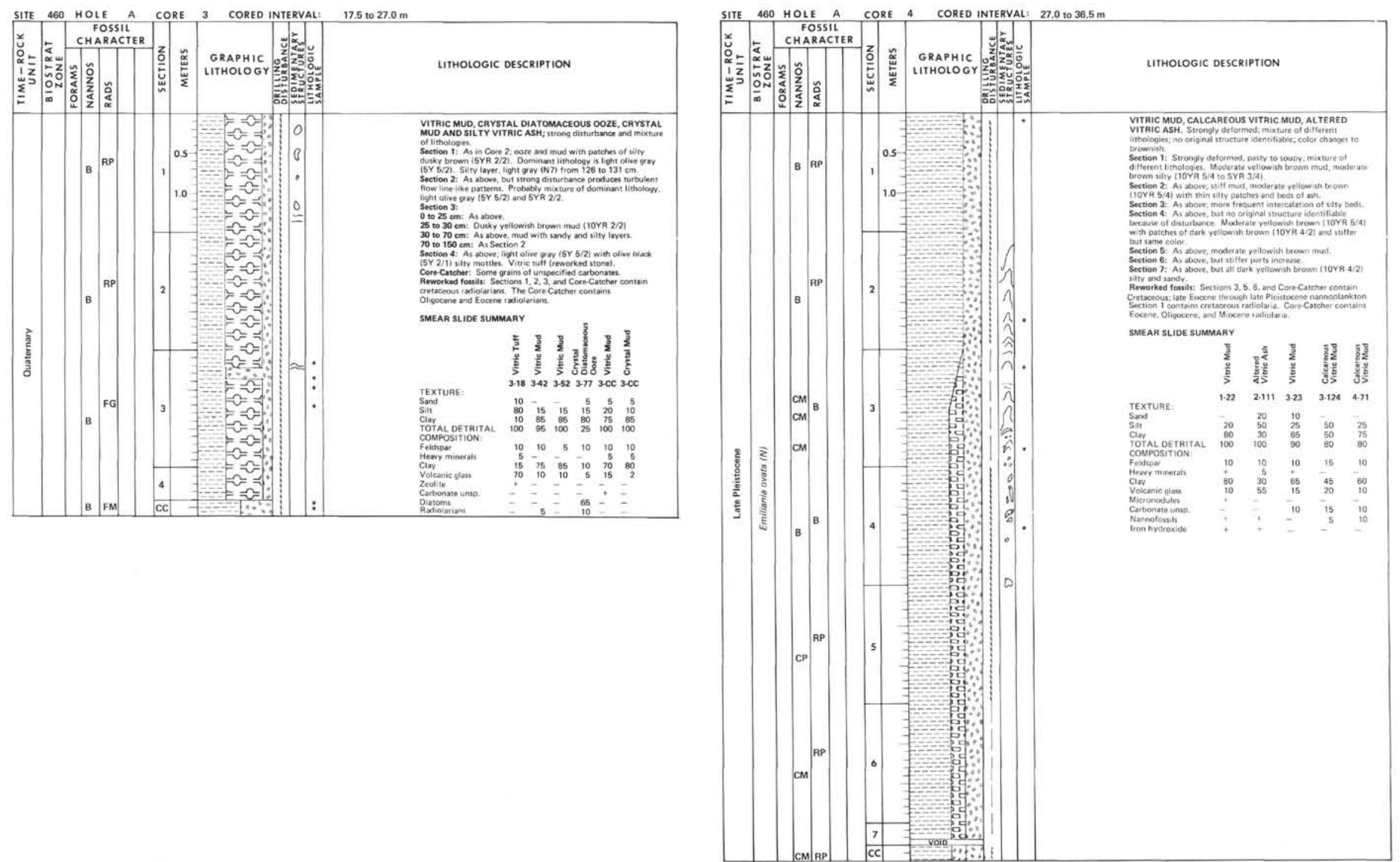


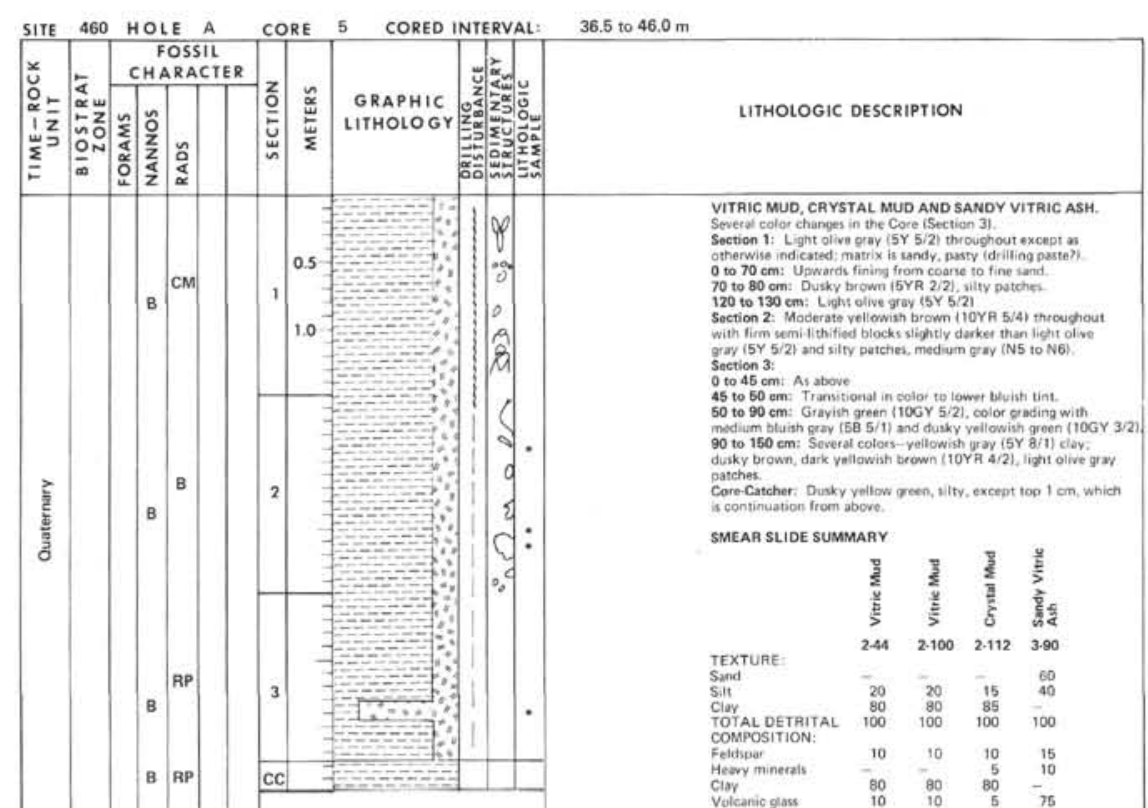

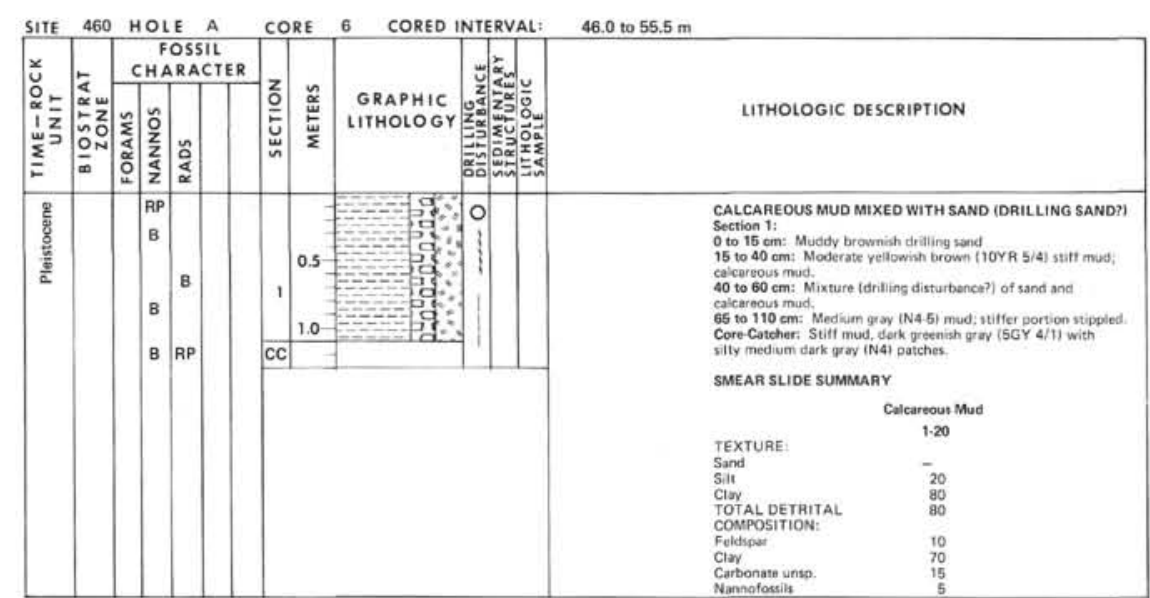

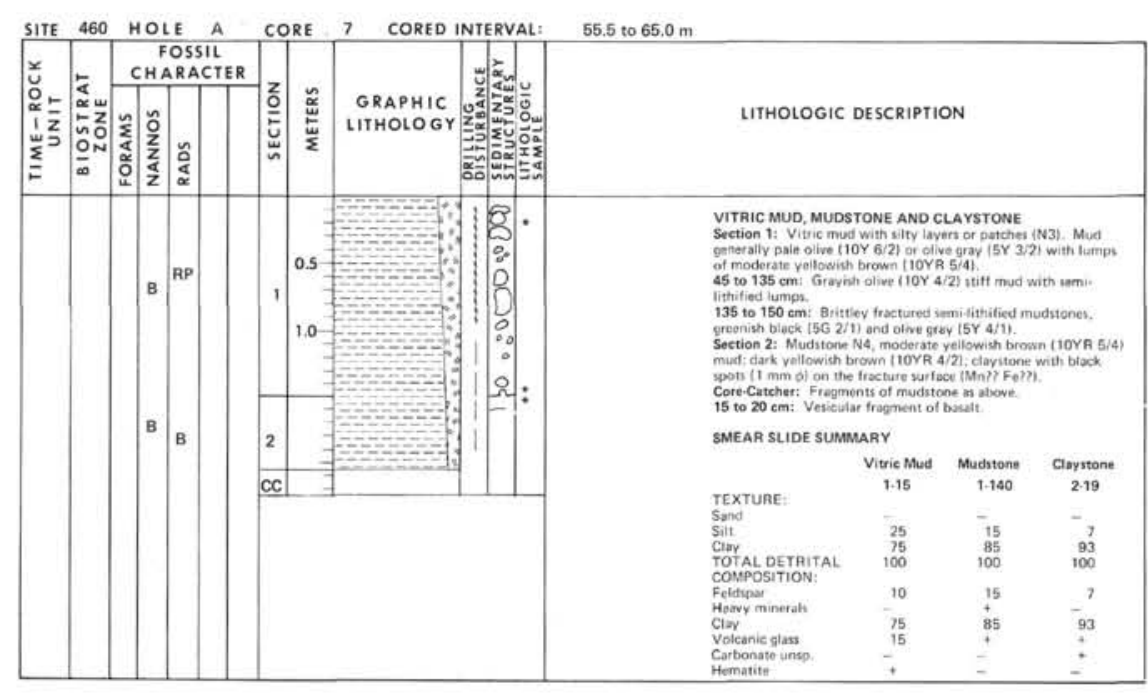

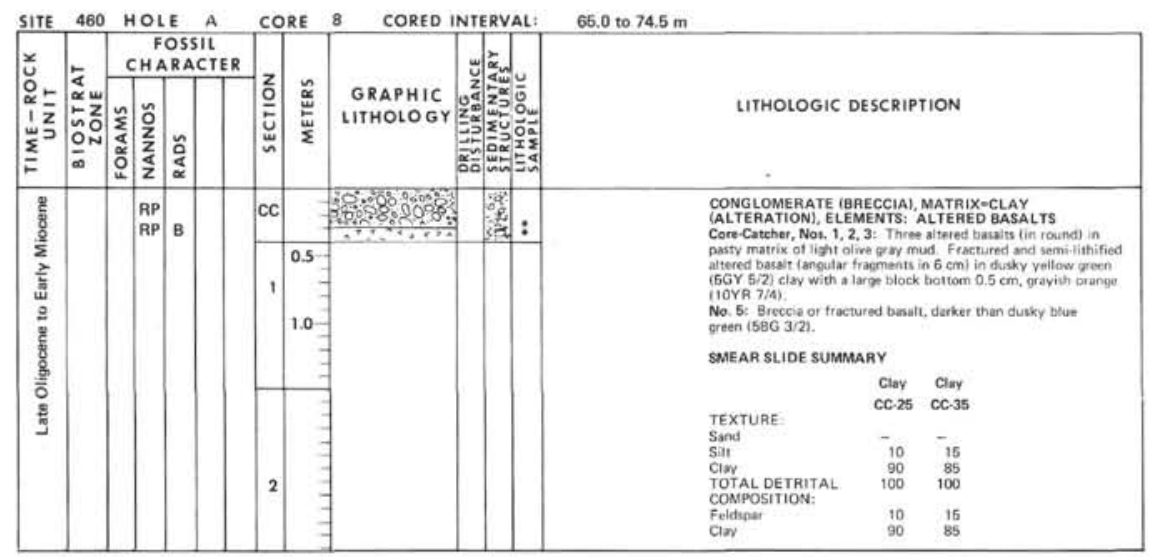




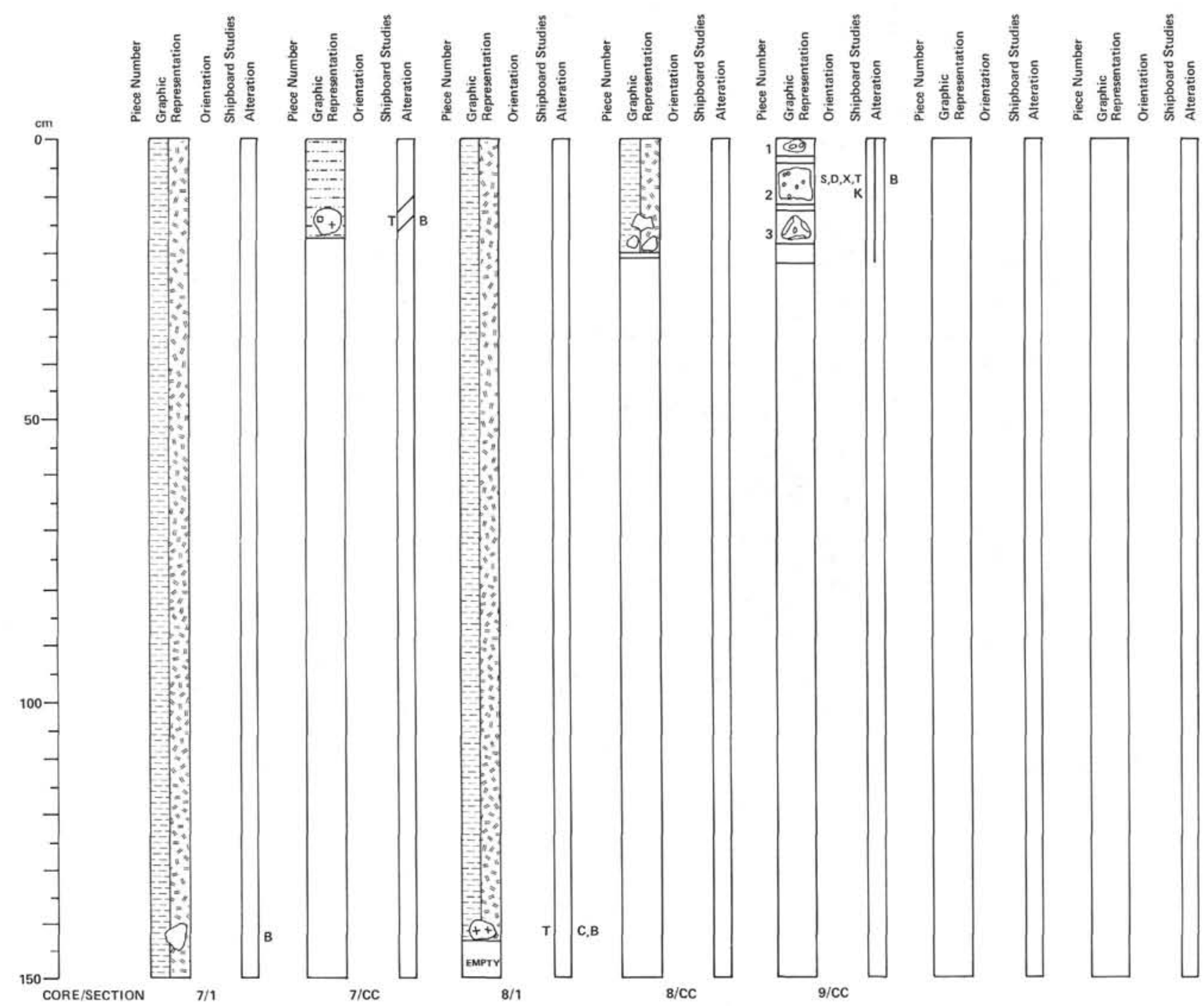

$460.9 . \mathrm{CC} \quad 6527.5 .6536 .5 \mathrm{~m}(76.085 .0 \mathrm{~m}, \mathrm{BSF})$

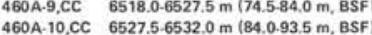

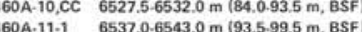

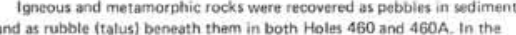

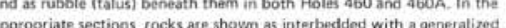
ediment type (vitric mudstone or mudstone) only. The reader is retertred sediments. The sedimentr descriotion sheets also contant the depth int sediments The sedime
mation for those crove

In both holes, seven different rock tvpes were identififed petrog raphicall

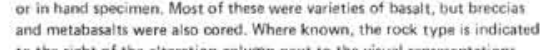

$\begin{array}{ll}8 & \text { - basalt } \\ \text { M } & =\text { metabosast }\end{array}$

CB Sive 458 to H $=$ hyalociast

BB - cemented basaltic breccia

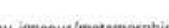

samples from this site.

Petrographic Summary

Descriptions are grouped by tock type, regarcliess of the holte of inturved.

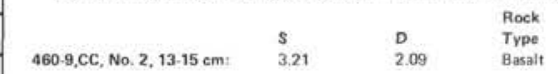

1

$-1$

- Sampla 460.8.1, $148.150 \mathrm{~cm}$ : a cobble with sedimants.

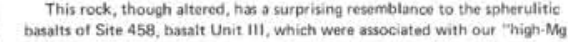
andesites." Acicular clinopyroxene microlites torm about $5 \%$ of the rock. A tew cliropyroxene miccrophenocryyts also occur, but orthopyroxene-pheno. Crysts are absent, Plagioclase is distinctly finer-grained occurting as needte-fike

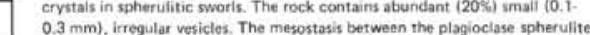
is attered to elayss and reddish iron-oxides. Clays also form thin linings in the - vesictes-

\section{Sparrely Plegioclase-Clinopyroxene Phyric or Aphyric Bosalts \\ Sparsely Plagiocelase-Clinopyroxene Ply
Characterized by Plagioclase Mierrolite}

Samples $460.7 .7 C, 12 \cdot 15 \mathrm{~cm}$, and $460 \mathrm{~A} \cdot 7, \mathrm{CC}, 145-147 \mathrm{~cm}$; both cobbles
in sediments: $460 \mathrm{~A} \cdot 9 . \mathrm{CCC}, 3.6 \mathrm{~cm}$ and $460 \mathrm{~A} \cdot 9, \mathrm{CC}, 12 \cdot 13 \mathrm{~cm}$; two rocks from the breccin or talus below tedimentin.

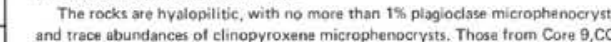
plagiociase microlites between 0.1 and 0.5 mm long comprise betweer $5 \%$ and secondary minerats. The 9:CC

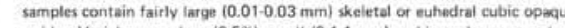
in shape.

The merostasis altered into two distinct tvpes of material. About
$40.45 \%$ of the sections consist of pale green, pale oranger or clear clays 40.-45\% of the sections consist of pale green, pale orangec, or cleart
that are moderately bireffringent and fairty cystalline. The clays

appear to have replaced glass. The remainder of the metortasis is of dispersed hydrous iron-oxides and clays. Relict spherulitic texture can still be seen in thess zones: these probably were clinopyroxene
which supplicd the iron for the secondary hydrous iron-oxides

Altered Hyaloclastite

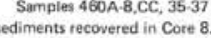

(5)

$5 \mathrm{~mm}$ in diameter, cemented in their own crushed qlass matrix. 


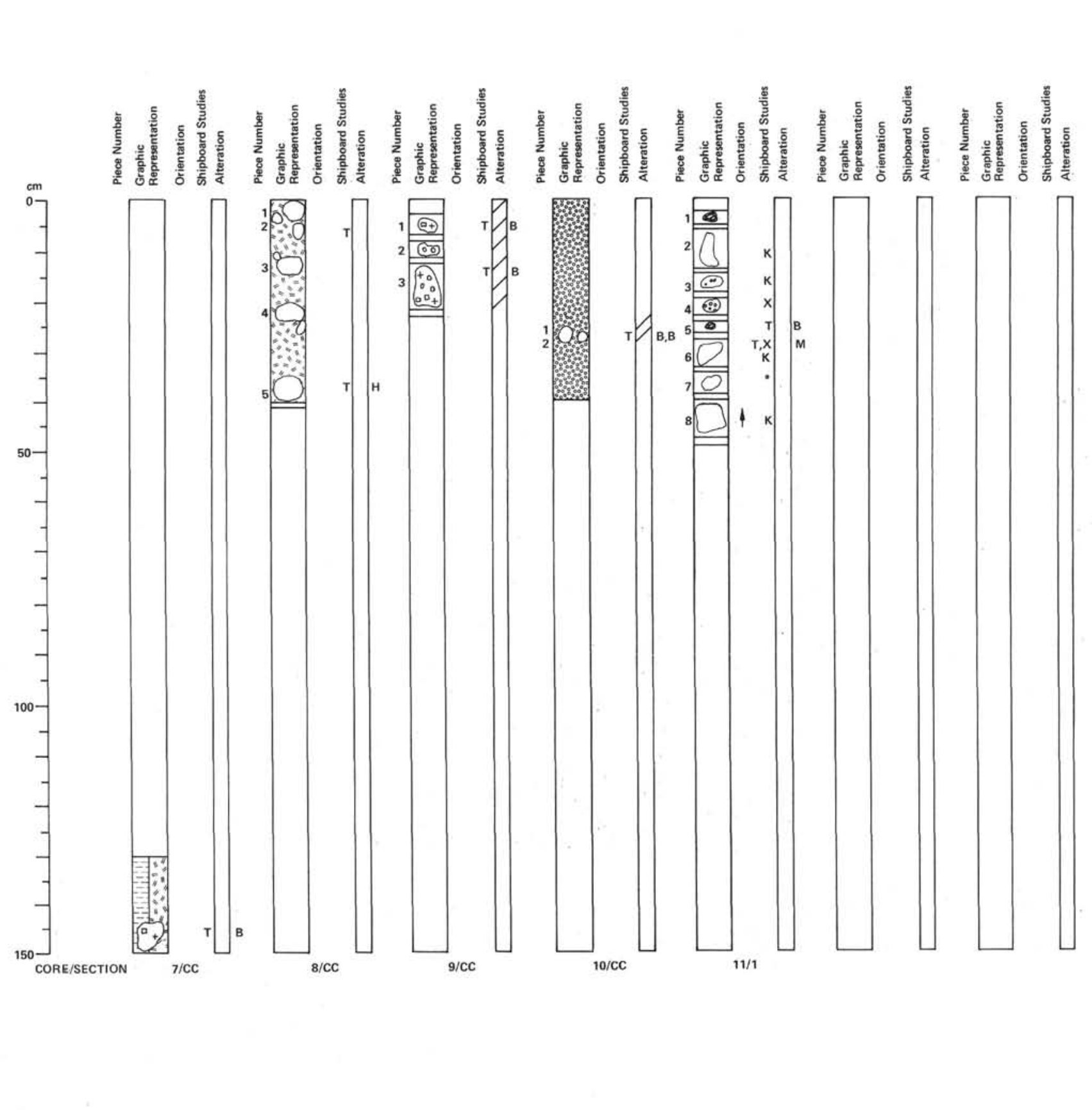

The extent of crystallinity of the frogments varies somewhat, but

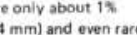
clinopyrtoxene microphenoctrysts, Both acicular plagioclase microli $\mathrm{mm}$ long) pervade the glass. Vesictes are rare (2\%) and small 102. $0.4 \mathrm{~mm}$ ), partialily filled with clays and zeolites. Zeolites and elays also cement the gass tragments.
Because

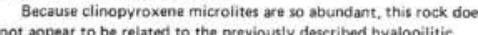

from Core 9,CC (the interval just below this samplee.

- Sparsely Plagioclase-Olivine-Clinopyroxene Phyric Basalt

of Hole 460 .

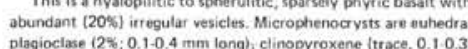

$\mathrm{mm}$ longl and altered pseudomorphs after euhedral olivine 0.1. $0.4 \mathrm{~mm}$ longl. The ofivines are completely attered to clays and

$0.10 .5 \mathrm{~mm}$ long) and abundor Tha mesortasis makes up about $40 \%$ of the rock and is altered to

- Ouartz-Cemented Aittered Basalt Breccis

Sample 460A $10, \mathrm{CC} .25 \cdot 27 \mathrm{~cm}$

breccia recovered in Core 10
The thin section consists of one large basaltic fragment and several up to $0.5 \mathrm{~mm}$ wide. These veins also contain weveral per cent por Quartz is perhaps $40 \%$ of the thin section, forming crystals in the in the groundmass of the basaltic tragments

was originally a single rock. They are aphyric, with about 5 so sciculas plagioclase niedies $0.10 .2 \mathrm{mim}$ long. The mesostasis, now almost

Glassy Plagioclase-Clinopyroxene Phyric Basalt Semple 460A-11 1, $25.26 \mathrm{~cm}$; pebble

This was one of two glassy samples recovered in Core 460A.11, and of the two is least glassy, and the only one from which a thin section microphenocerysts of plegioclase and clinopyroxene. Tho plagioclase pyroxene is pale green and taintly plechroic.

The groundmass contans about $15 \%$ of acicular to skeletal plagic long), and traces of opanue oxides There appeas to be two types of plagioclase, one acicular, the other platy and enciosing the acicular Crystalis.
The glass is a rich reddish -brown color. Near vesicles, though,
is boundary with the reddish brown glass. This vellow glass is taintiv
bireftringent because of the presence of dispersed clays. It may be bireftingent beciuse of the presencen of dispersed clavs. It may be
a type of poorly crystalline palagonite.

Vesicies are sparse $(3.5 \%)$, small $10.10 .5 \mathrm{~mm}$ ) and round or giass

- Ouarce.Amphibole-Pragiociase Metabasalts

Samples $460 \mathrm{~A} \cdot 11-1,29.31 \mathrm{~cm}$ and $460 \mathrm{~A}$-center bit; these are the deepest rocks recovereded in Hole $460 \mathrm{~A}$.

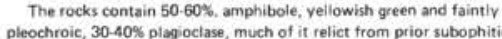
textures, and $7.10 \%$ quartz, in parches between the foldspars and amphiboles. Traces of magnetite are present, as are traces of relict clinopyroxene in the amphibole. The amphibole mantling these
relict pyroxanes is crudaly poikilobiastic, but follation is absent.

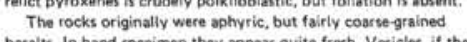

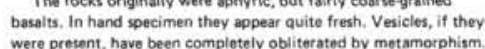




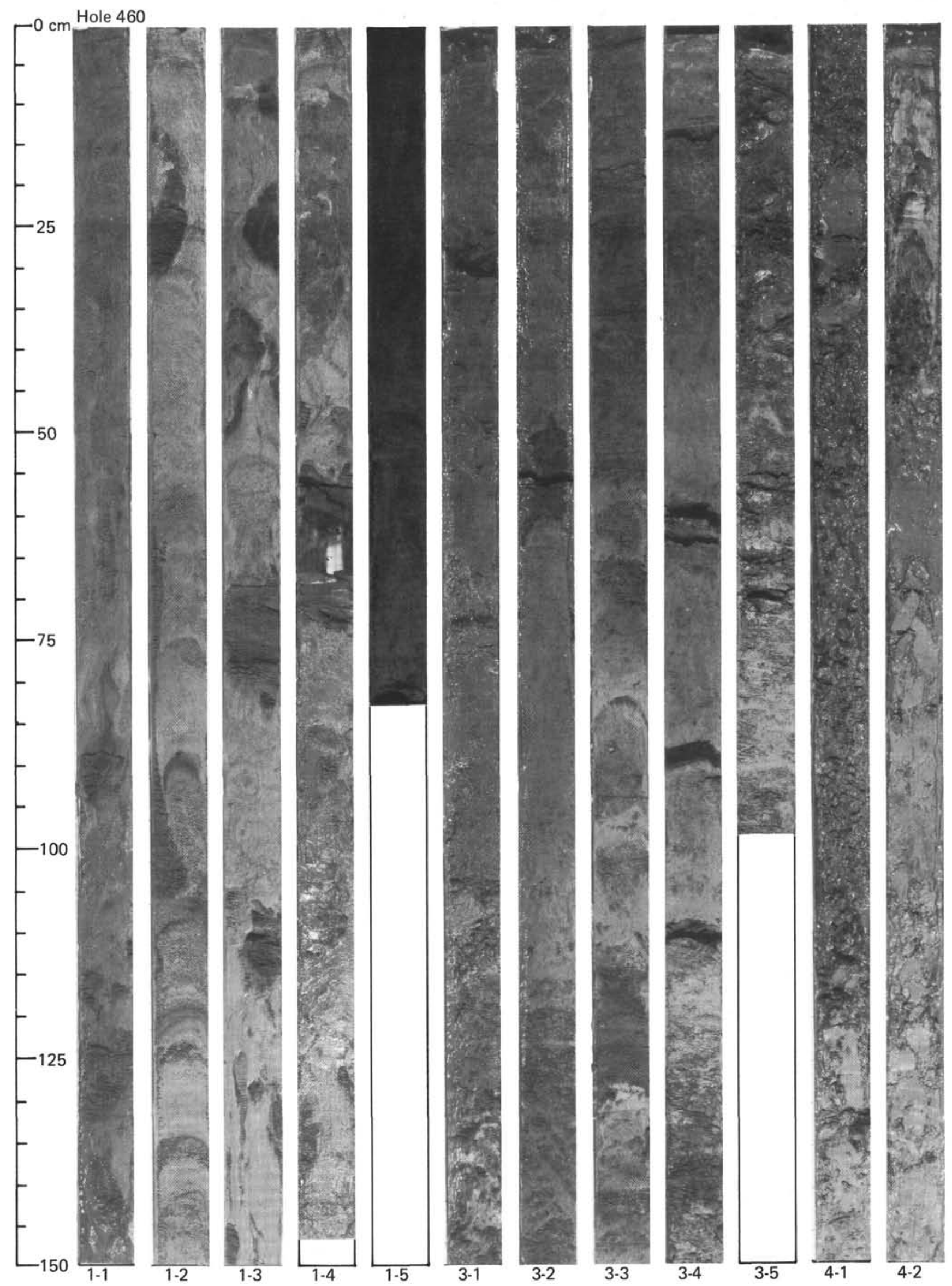



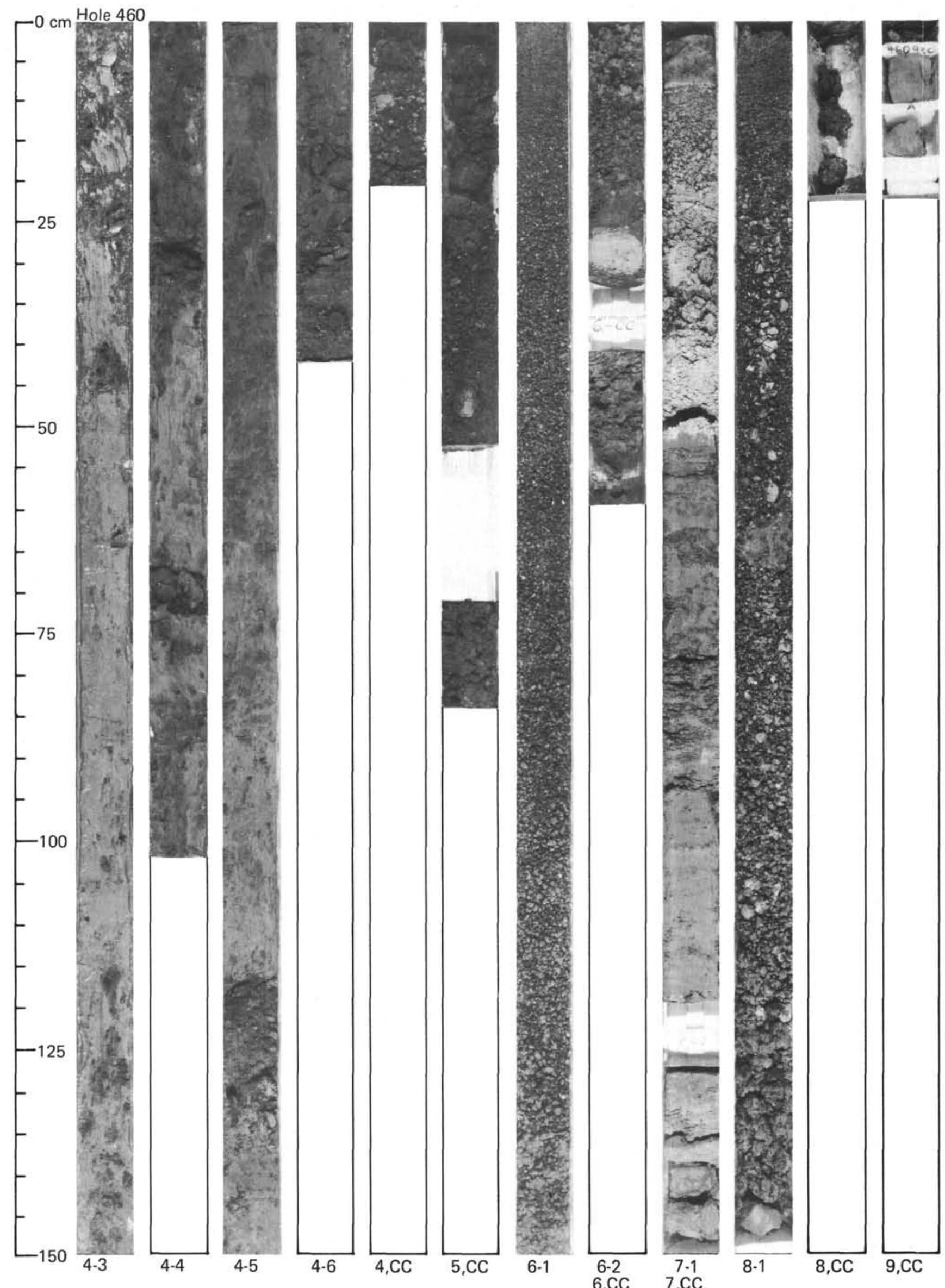

.
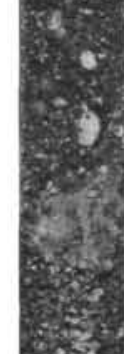

5
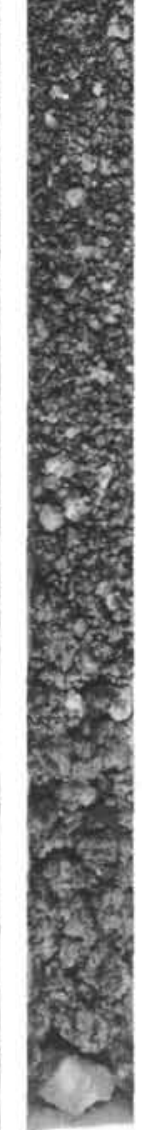

$8-1$ 8,CC

(CC 
SITE 460

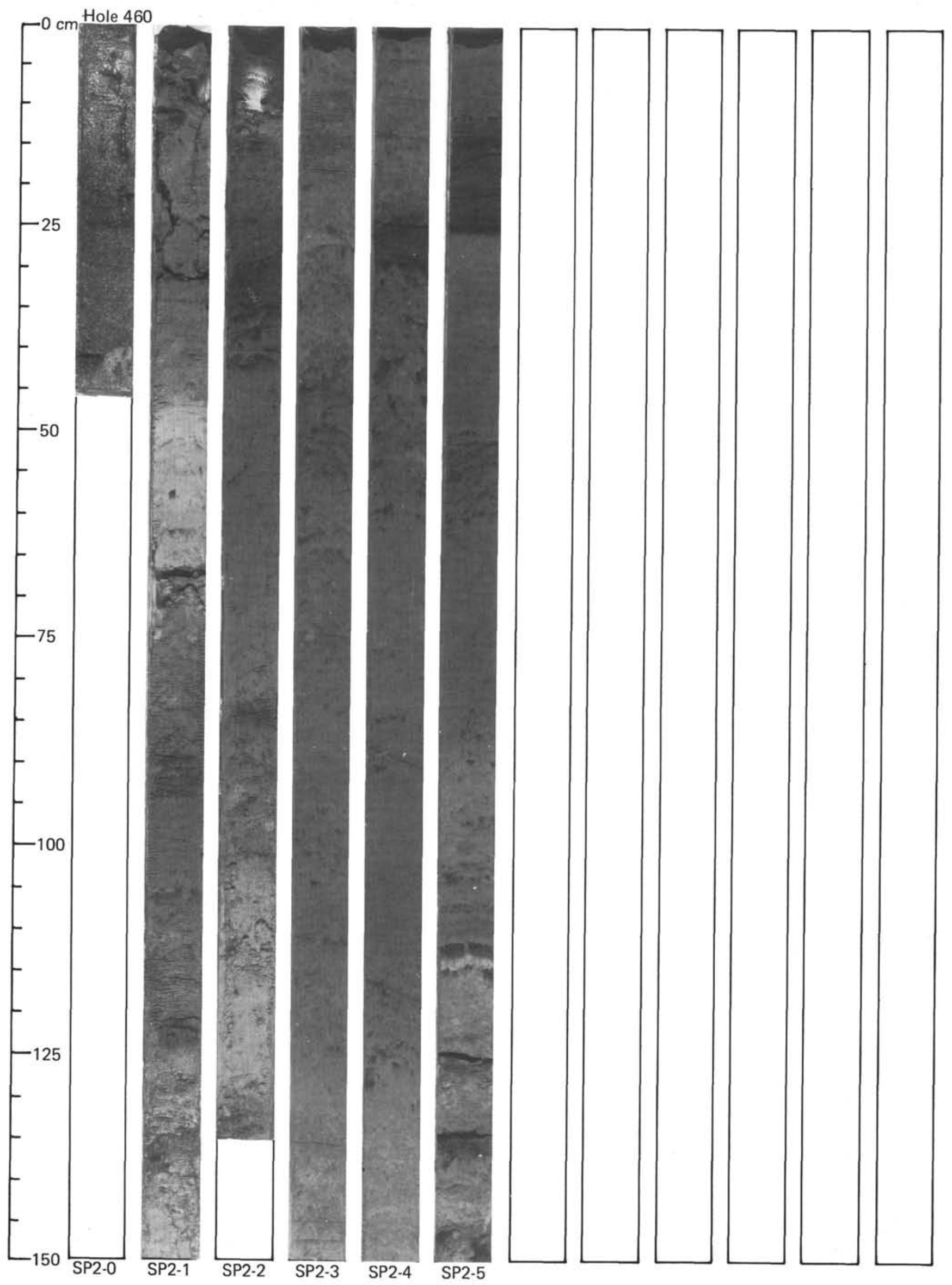




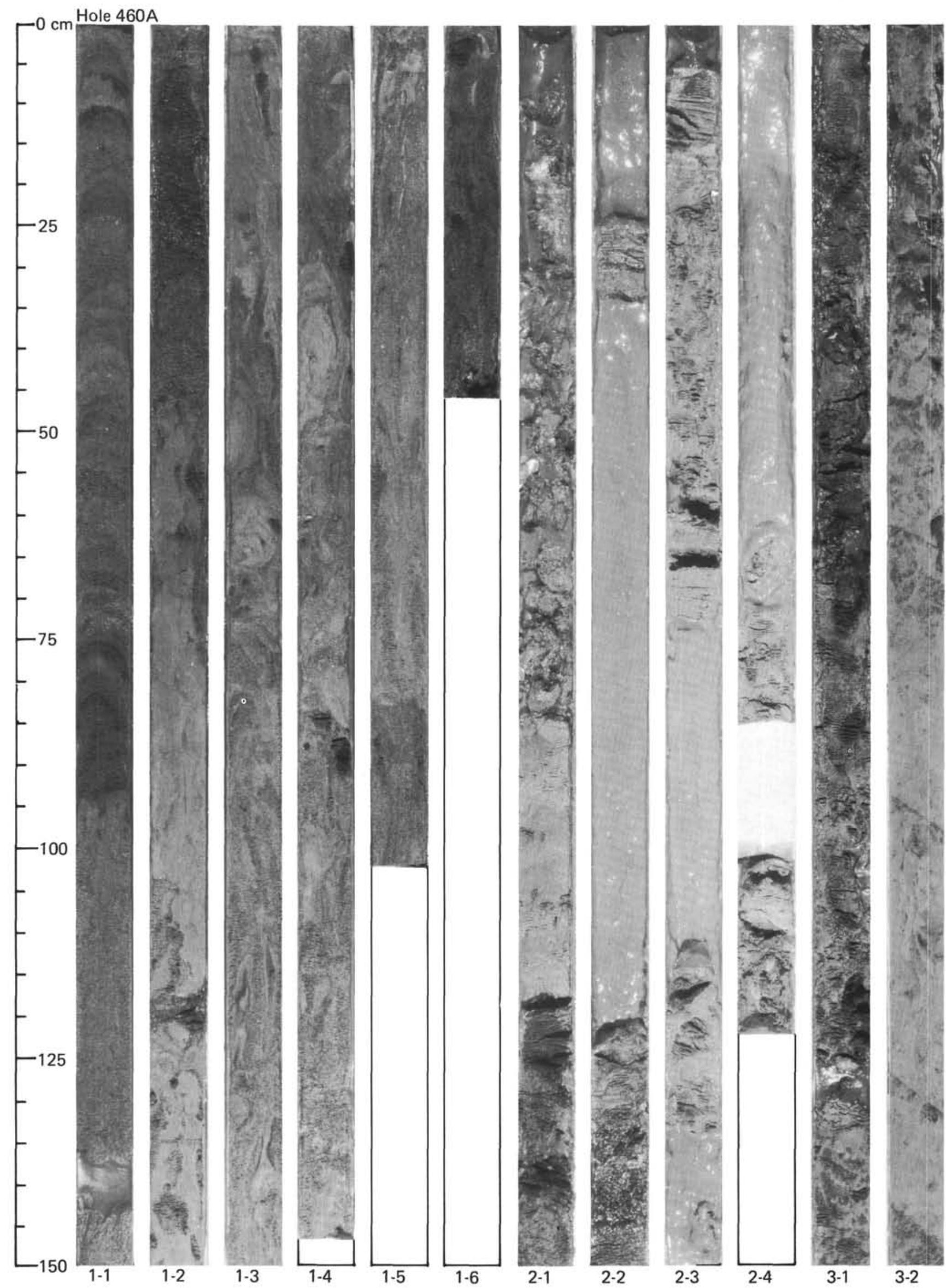




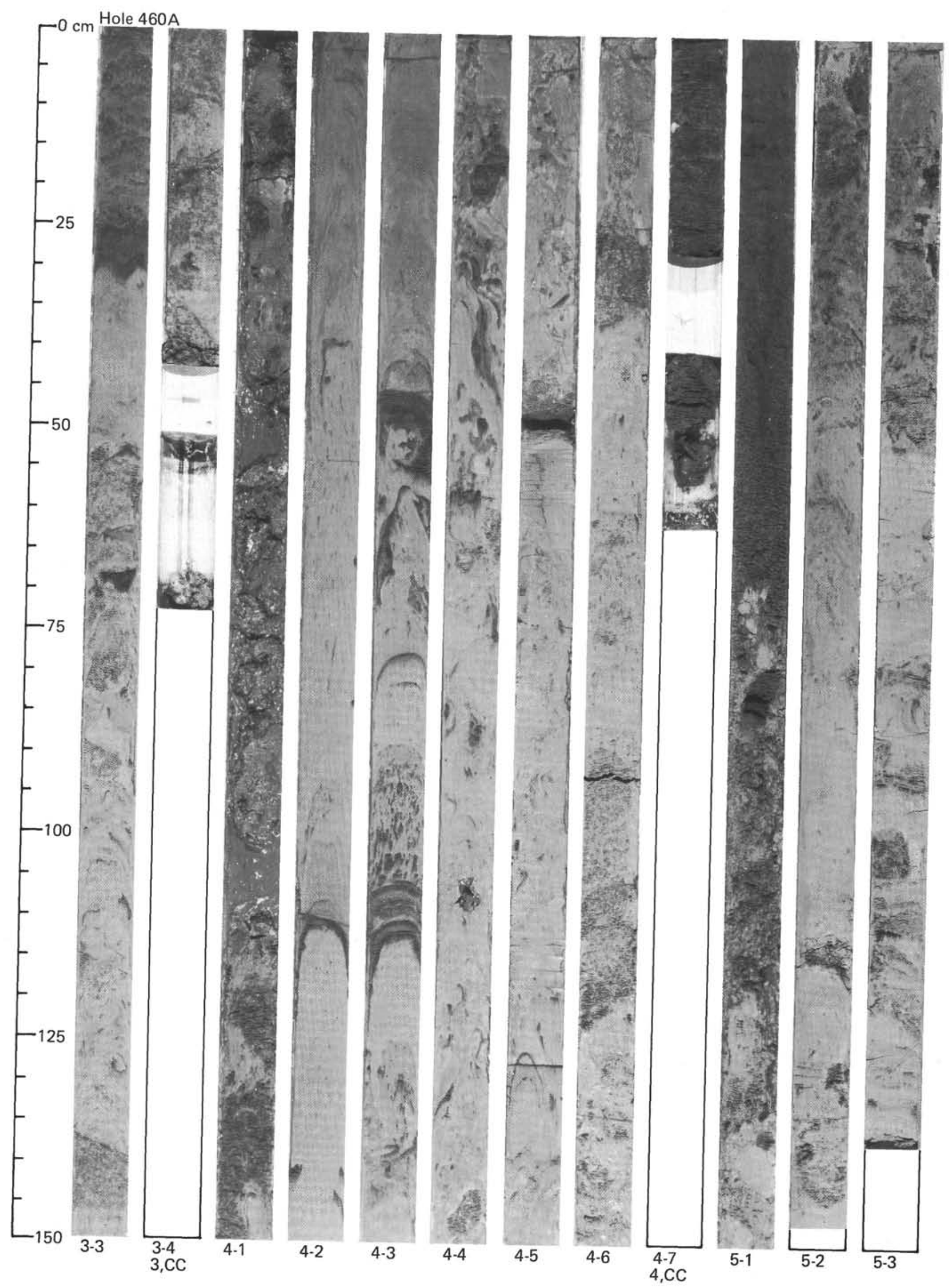




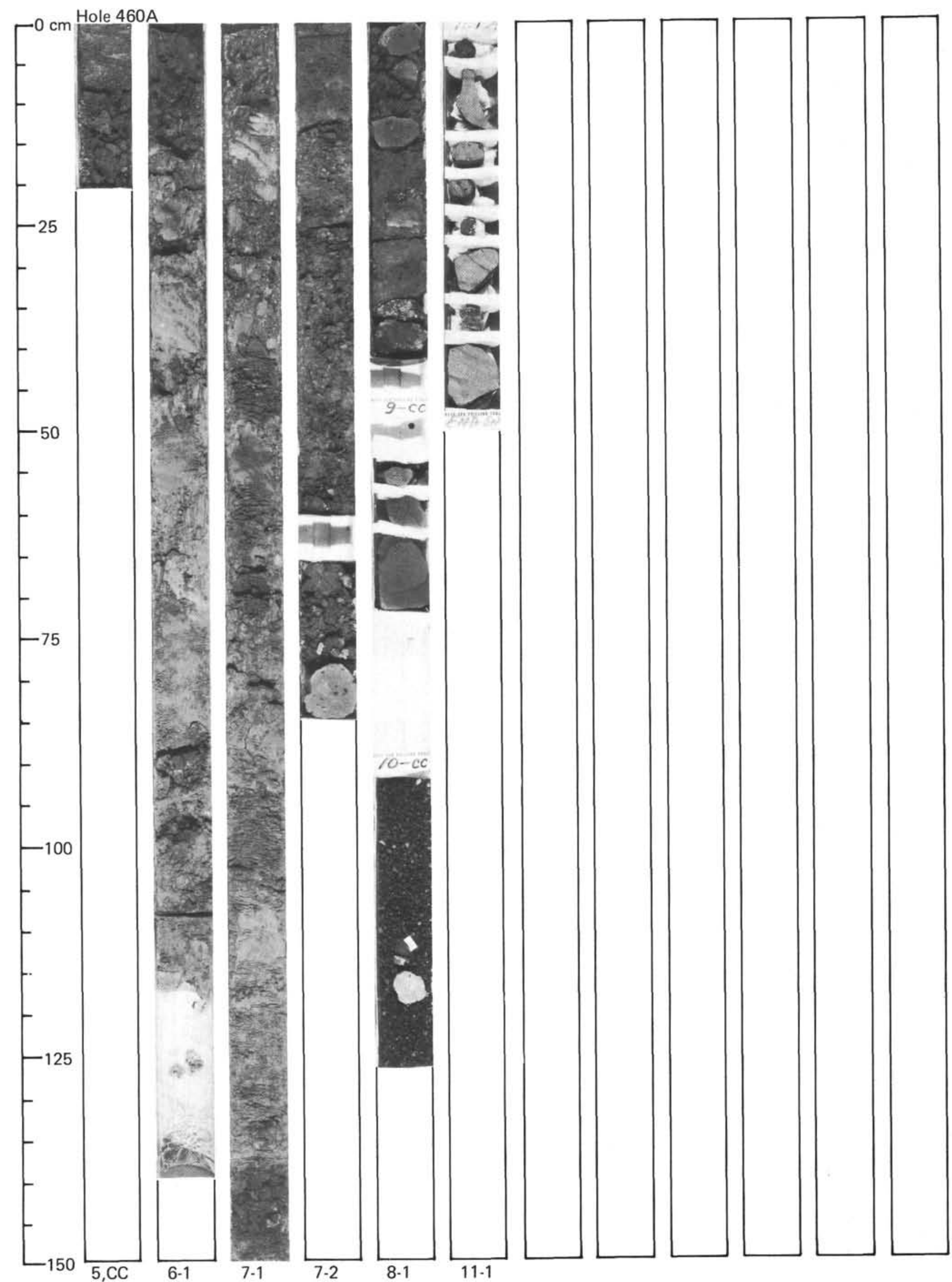

